Summary of the Geology, Economic Aspects, and Geochemistry of the Schwartzwalder Uranium-bearing Area, Ralston Buttes District, Jefferson County, Colorado

U.S. G E O L O G I A L S URVEY B ULLET I N 1555 



\section{Summary of the Geology, Economic Aspects, and Geochemistry of the Schwartzwalder Uranium-bearing Area, Ralston Buttes District, Jefferson County, Colorado}

By E. J. YOUNG

U.S. G E O L O G I A L S U R V E Y B U L LE T I N 1555

A study of relations between uraniferous mines and prospects in the Front Range near Golden, Colorado

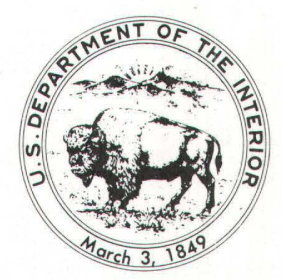




\section{DEPARTMENT OF THE INTERIOR \\ DONALD PAUL HODEL, Secretary}

\section{U.S. GEOLOGICAL SURVEY}

Dallas L. Peck, Director

\section{Library of Congress Cataloging in Publication Data}

Young, Edward J. (Edward Joseph), 1923-

Summary of the geology, economic aspects, and geochemistry of the Schwartzwalder uraniumbearing area, Ralston Buttes district, Jefferson County, Colorado.

(Geological Survey bulletin ; 1555)

Bibliography: $p$.

Supt. of Docs. no.: I 19.3:1555

1. Geology-Colorado-Jefferson County. 2. Uranium mines and mining-Colorado-Jefferson County. 3. Geochemistry-Colorado-Jefferson County. I. Title. Series. 


\section{CONTENTS}

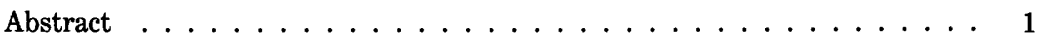

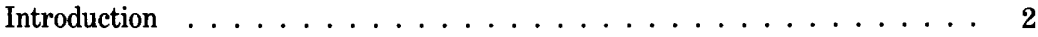

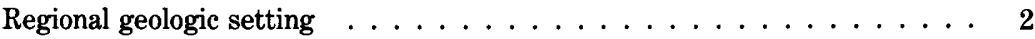

Rocks of the map area . . . . . . . . . . . . . . . 5

Precambrian rocks . . . . . . . . . . . . . . . . . . 5

Metamorphosed sedimentary and volcanic rocks . . . . . . . 5

Cataclastic rocks .................. 8

Igneous and metaigneous rocks $\ldots \ldots \ldots \ldots$

Paleozoic sedimentary rocks $\ldots \ldots \ldots \ldots . \ldots . \ldots 9$

Tertiary intrusive rocks . . . . . . . . . . . . . . 9

Cenozoic surficial deposits $\ldots \ldots \ldots \ldots \ldots$

Quaternary deposits . . . . . . . . . . . . . 10

Pleistocene, lower . . . . . . . . . . . . . . 10

Pleistocene, upper . . . . . . . . . . . . . 10

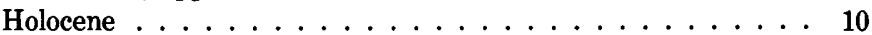

Structural geology ..................... 11

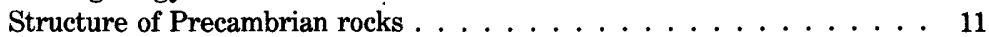

Folding ......................... 11

Idaho Springs-Ralston shear zone . . . . . . . . . . 13

Breccia reefs . . . . . . . . . . . . . . 13

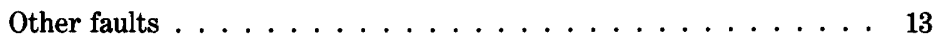

Folds and faults in Paleozoic rocks . . . . . . . . . . . 15

Radiometric and mineralogic data . . . . . . . . . . . . . 15

Economic geology . . . . . . . . . . . . . . . . . 16

Schwartzwalder Mine . . . . . . . . . . . . . . . 16

Mena Mine . . . . . . . . . . . . . . . . . . . . . 19

North $\operatorname{Star}$ Mine . . . . . . . . . . . . . . . . . . 21

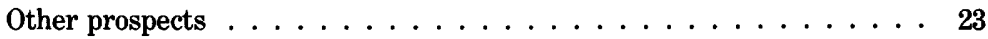

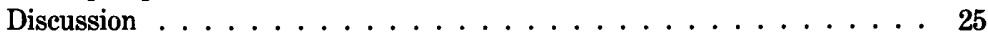

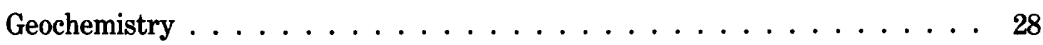

References ........................ 31

\section{ILLUSTRATIONS}

Plate 1. Geologic map of the Schwartzwalder area . . . . . . . . In pocket

2. Radiometric and mineralogic map of the Schwartzwalder area ................... In pocket 
Figure 1. Outline of the Front Range, Colo., location of the Ralston Buttes district, Schwartzwalder Mine, and Front Range mineral belt . . . 3

2. Index map showing location of map area and regional geology . . . 4

3. Lower hemisphere projection of 633 poles to foliation on equal-area net, contoured in percent of poles per percent area . . . . . . 11

4. Lower hemisphere projection of $\mathbf{5 8}$ lineations on equal-area net, contoured in percent of poles per percent area. . . . . . . . 12

5. Plane table map of critical area in SE $1 / 4$ sec. 25, T. 2 S., R. $71 \mathrm{~W}$. 14

6. Diagrammatic cross section through the Schwartzwalder deposit illustrating sequence of events leading to uranium deposition . . . .

\section{TABLES}

TABLE 1. Average modal mineralogy of major rock units in the Schwartzwalder

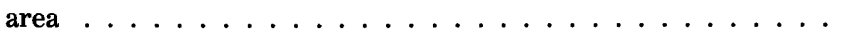

2. Scintillometer readings in counts per second of rocks in the Schwartz-

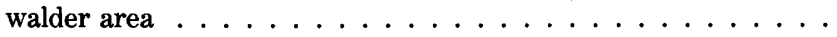

3. Distribution and concentration of elements, relative to crustal abundance, in Schwartzwalder pitchblende ore . . . . . . . . .

4. Distribution and concentration of elements, relative to crustal abundance, in two ore samples from the Mena Mine . . . . . . . . .

5. Distribution and concentration of elements, relative to crustal abundance, in ore samples from the North Star Mine . . . . . . . .

6. Spectrographic analyses of ore samples from six prospects in the Ralston Buttes district and enrichment factors of the detected ele-

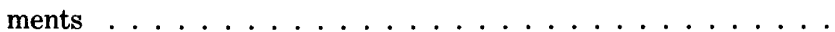

7. Relative abundance of elements in underground host rocks of the Schwartzwalder deposit . . . . . . . . . . . . . . . .

8. Relative abundance of elements in surface country rocks near the Schwartzwalder deposit . . . . . . . . . . . . . .

9. Relative abundance of elements in nine surface and two underground fault breccias ................... 


\title{
SUMMARY OF THE GEOLOGY, ECONOMIC ASPECTS, AND GEOCHEMISTRY OF THE SCHWARTZWALDER URANIUM-BEARING AREA, RALSTON BUTTES DISTRICT, JEFFERSON COUNTY, COLORADO
}

\author{
By E. J. YounG
}

\begin{abstract}
The most productive vein uranium deposit in the Colorado Front Range and, indeed, in the United States is the Schwartzwalder. Ultimate production may be 10 million $\mathrm{kg} \mathrm{U}_{3} \mathrm{O}_{8}$, or more. The Schwartzwalder deposit is $13 \mathrm{~km}$ southeast of the Front Range mineral belt, in Precambrian metamorphic country rocks, but is less than $0.8 \mathrm{~km}$ distant from sedimentary rocks ranging in age from Pennsylvanian to early Tertiary. After at least three episodes of Precambrian folding succeeded by an episode of faulting that produced northwest-trending faults, the Laramide orogeny caused upturning and folding of sedimentary strata along the mountain front, reactivated the Precambrian northwest-trending faults, and initiated new faulting and fracturing in the Schwartzwalder area. During Laramide time, about $62 \mathrm{~m} . \mathrm{y}$. ago, the Ralston dike, of mafic monzonite, was intruded along the Golden fault.
\end{abstract}

The Precambrian rocks consist of metamorphosed sedimentary and volcanic rocks (mica schist, quartzite, hornblende gneiss, granite gneiss, and a magnetite and quartz layer), cataclastic rocks (granite gneiss and biotite schist), igneous and metaigneous rocks (pegmatite, hornblende diorite, and hornblendite), and quartz veins. Paleozoic sedimentary rocks consist of the Pennsylvanian and Permian Fountain Formation and the Permian Lyons Sandstone. A small mafic monzonite dike of Laramide age occurs $1.9 \mathrm{~km}$ northwest of the Schwartzwalder; the Ralston dike is $3.6 \mathrm{~km}$ southeast. Several Quaternary surficial deposits complete the geologic succession.

The major fold of the mapped area is a steeply dipping, asymmetric synform in mica schist that plunges $45^{\circ}-68^{\circ}$ west-southwest. The compressed apical part of the synform is the country rock for almost all the pitchblende veins in the Schwartzwalder deposit. The northeasterly striking Idaho Springs-Ralston shear zone is probably a limiting boundary for uranium mineralization. A set of northwest-trending breccia-reef faults showing little or no displacement is interpreted as the conduit for uranium migration.

The Schwartzwalder is a prime example of a structurally controlled ore deposit. Shearing, developed in the cymoid zone of the Illinois fault, produced the opening of many horsetail fractures, which provided sites for uranium deposition about $60 \mathrm{~m} . \mathrm{y}$. ago. Pyrite and minor amounts of lead, molybdenum, and zinc sulfides accompany the 
pitchblende, which contains significant amounts of high-valent elements, such as antimony, tungsten, and thallium.

The Mena and North Star Mines of the Ralston Buttes district differ from the Schwartzwalder in being very small producers and richer in bismuth, copper, and silver than in uranium. The ores from six additional prospects show geochemical affinities to the Mena and North Star Mines rather than to the Schwartzwalder.

Geochemical data in and around the Schwartzwalder deposit suggest that the surface country rocks (mainly Precambrian schists and gneisses) are not the source of the uranium and base metals. Underground host rocks of the same lithotypes show enrichment in 11 elements, similar to the enrichment in the pitchblende veins, because of infiltration of ore fluids through microfractures in proximity to the pitchblende veins. Fault breccias, both underground and surface, also show enrichment in the same elements as the pitchblende veins.

\section{INTRODUGTION}

The Schwartzwalder uranium deposit has become the most productive vein uranium deposit in the Front Range and, indeed, in the United States. Total production is about 5 million $\mathrm{kg} \mathrm{U}_{3} \mathrm{O}_{8}$, and ultimate production may be more than twice that amount. About 97 percent of all uranium produced from veins in the Front Range has come from this ore deposit.

The Schwartzwalder Mine is about $13 \mathrm{~km}$ northwest of Golden in the SE $1 / 4$ sec. 25, T. 2 S., R. 71 W., in the Ralston Buttes district, Jefferson County, Colo. (fig. 1).

Detailed geologic and radiometric mapping of $18 \mathrm{~km}^{2}$ (area shown on fig. 2) was undertaken intermittently from 1973 to 1975 on a 1:12,000 topographic base. The main objective was to map the Schwartzwalder area in greater detail than heretofore. (See plates 1 and 2.)

A description of the Schwartzwalder Mine and a smaller area (3.4 $\mathrm{km}^{2}$ ) around the mine was released previously (Young, 1977). A report on the genesis of the Schwartzwalder deposit (Young, 1979b) and a tabulation of analytical data (Young, 1979a) were recently published. The most detailed published map of the Ralston Buttes district is that of Sheridan and others (1967) at a scale of 1:24,000.

\section{REGIONAL GEOLOGIC SETTING}

The Schwartzwalder deposit is in the east-central part of the Front Range, about $13 \mathrm{~km}$ southeast of the northeast-trending Front Range mineral belt. Figure 2 shows generalized geology in the vicinity of the Schwartzwalder Mine and the inactive Mena and North Star Mines. Although the uranium deposits occur in Precambrian metamorphic country rocks, the Schwartzwalder deposit is less than $0.8 \mathrm{~km}$ distant from sedimentary rocks ranging in age from Pennsylvanian to early Tertiary. The proximity of the deposit to the sedimentary rocks is thought to be significant. (See fig. 6.) 


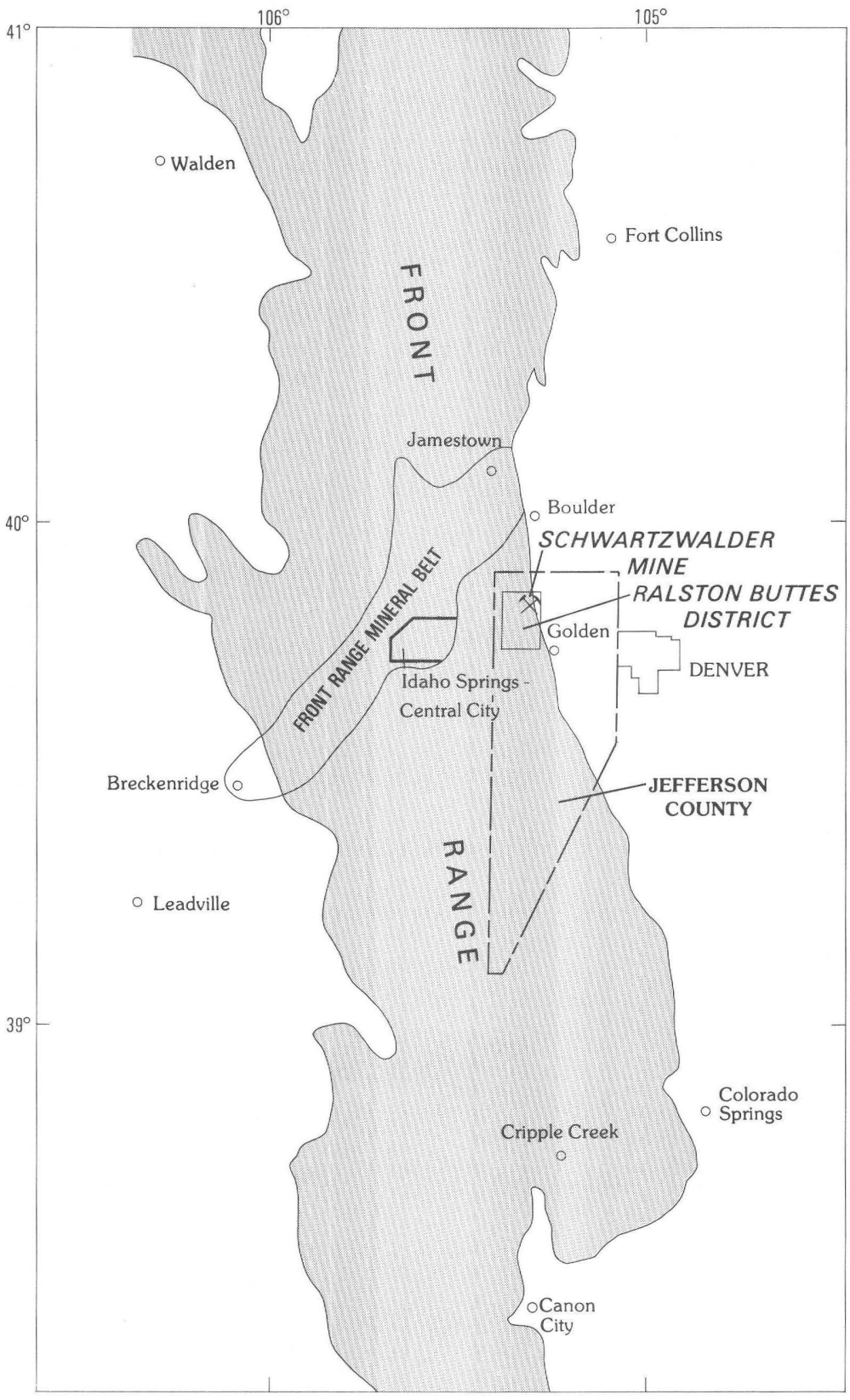

$\begin{array}{llllll}8 & 10 & 20 & 30 & 40 & 50 \\ \text { KILOMETERS }\end{array}$

FiguRe 1.-The Front Range, Colo., location of the Ralston Buttes district, Schwartzwalder Mine, and Front Range mineral belt (from Sheridan and others, 1967, fig. 2). 


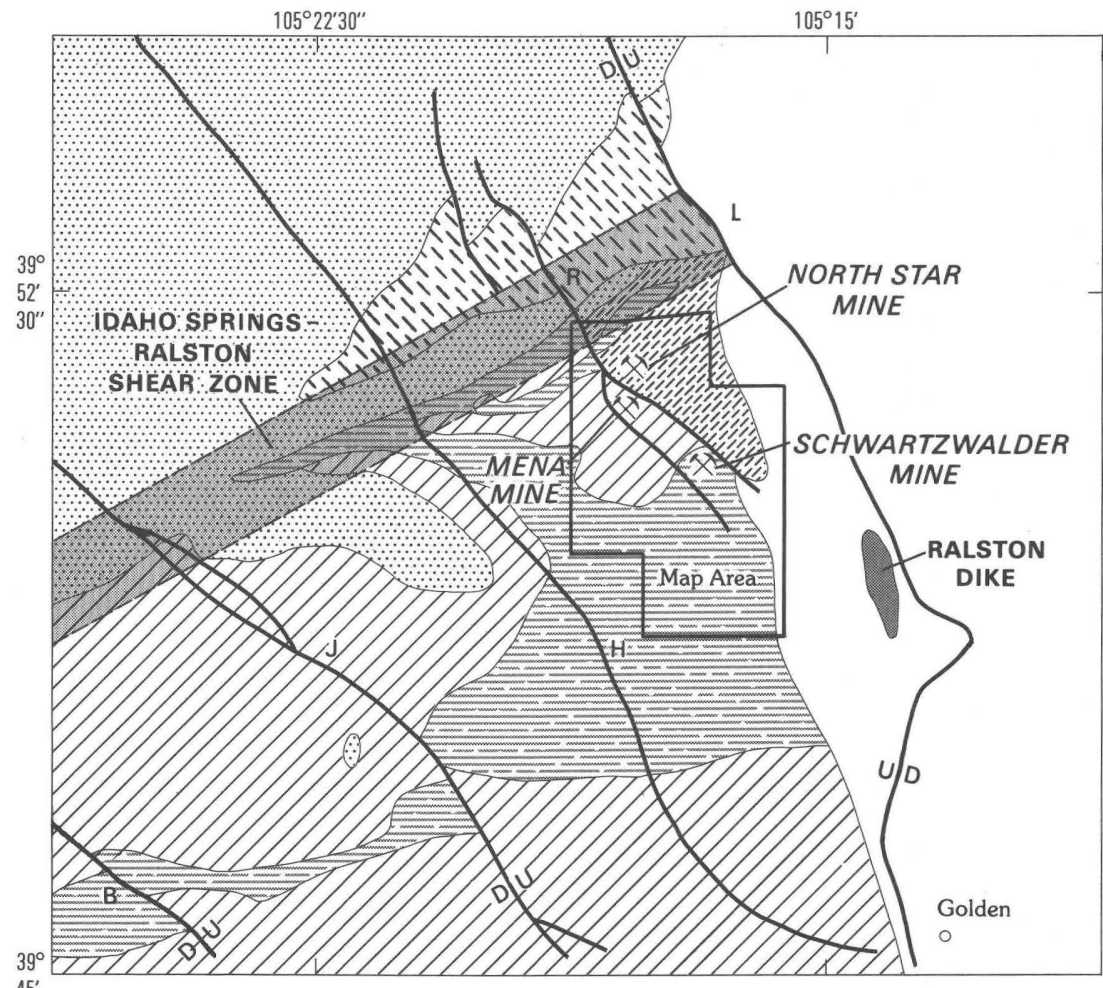

$45^{\prime}$

0 5 KILOMETERS
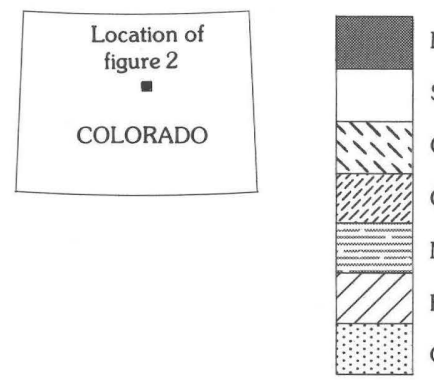

EXPLANATION

Mafic monzonite

Sedimentary rocks

Quartzite

Granite gneiss

Mica schist

Hornblende gneiss

Granodiorite and quartz monzonite

\section{PALEOCENE \\ PALEOZOIC \\ AND \\ MESOZOIC}

PRECAMBRIAN

\footnotetext{
$\frac{D}{U}$ Fault, showing relative

movement, where known.

$\mathrm{D}$, downthrown; U, upthrown.

Outline of Idaho Springs-
}

- Ralston shear zone

FIGURE 2.-Location of map area and regional geology. Precambrian faults are identified as follows: B, Black Hawk; J, Junction Ranch; H, Hurricane Hill; R, Rogers, east and west branches; L, Livingstone (southern extension of Livingstone fault is known as the Golden fault in Golden area). (Modified from Taylor, 1975.) 
Three periods of Precambrian folding, succeeded by northwesttrending faulting (also Precambrian), have been recognized in the region (Taylor, 1975). The sedimentary succession that flanks the Precambrian core of the range begins with the Pennsylvanian and Permian Fountain Formation, which was deposited directly on the Precambrian basement following a long erosional interval. This unconformity is characterized by a relatively soft, red, weathered zone (regolith) as much as $6 \mathrm{~m}$ thick in the Precambrian rocks. Laramide uplift of the Front Range began in Late Cretaceous time (67 m.y. ago) and generally ceased in the middle Eocene $(45 \mathrm{~m} . \mathrm{y}$. ago). This orogeny caused upturning and folding of the sedimentary strata along the mountain front, reactivated the Precambrian northwest-trending faults, and initiated new faulting and fracturing in the Schwartzwalder area and elsewhere. The Ralston dike, of mafic monzonite, and several related, smaller intrusions were emplaced in or near the Golden fault about $62 \mathrm{~m} . \mathrm{y}$. ago during late stages of movement on the Golden fault (Van Horn, 1976).

\section{ROCKS OF THE MAP AREA}

Predominant rocks of the map area (pl. 1) are Precambrian crystalline rocks (formerly called Idaho Springs Formation-see Tweto, 1977), Paleozoic sedimentary rocks, and Cenozoic surficial deposits. Tertiary igneous intrusive rocks are represented by one small dike.

\section{PRECAMBRIAN ROCKS}

\section{METAMORPHOSED SEDIMENTARY AND VOLCANIC ROCKS}

Biotite-muscovite schist (Xs).-The schist unit occupies the southern half of the map area. The north boundary of the schist is a transitional contact with hornblende gneiss. On the east, the schist is overlain unconformably by the eastward-dipping Pennsylvanian and Permian Fountain Formation. Beneath the contact with the Fountain the schist shows a soft, red, weathered zone (regolith) as much as $6 \mathrm{~m}$ thick. The schist is commonly fine grained $(0.1-1.0 \mathrm{~mm})$ and contains at least 14 minerals, but not all in any one specimen (table 1). About half of the schist is composed of quartz, suggesting a clastic, metasedimentary origin. Pegmatites are more common in the schist than in any other rock unit. Porphyroblasts of andalusite attain lath sizes of $60 \times 2.5 \mathrm{~cm}$ in the western part of the area, but most appear as knobby relicts, 1 or $2 \mathrm{~cm}$ in length, in outcrops. Staurolite is not as abundant, but appears as knobby dark brown relicts as large as $1 \mathrm{~cm}$ in length in outcrops. Fine-grained, black tourmaline locally forms a significant part of the schist and has been found as fillings 
TABLE 1.-Average modal mineralogy of major rock units in the Schwartzwalder area

[Shown in volume percentages. Tr., trace; leaders (--) indicate not present]

\begin{tabular}{|c|c|c|c|c|}
\hline Map symbol------ & $X_{s}$ & $x q$ & $x h$ & $\mathrm{xgg}$ \\
\hline Quartz-- & 48 & 75 & 17 & 44 \\
\hline Muscovite---_-_-_- & 14 & 4 & - & 2 \\
\hline Biotite-1-- & 18 & 11 & 5 & 4 \\
\hline Hornblende-1.-... & -- & - & 36 & -- \\
\hline Plagioclase------ & 6 & -- & 35 & 36 \\
\hline Potash feldspar-- & -- & 1 & -- & 13 \\
\hline Garnet-- & 2 & 5 & 1 & -- \\
\hline Chlorite-n-n & 1 & -- & 2 & -- \\
\hline Tourmal ine-...... & 2 & -- & -- & -- \\
\hline Black opaque--.--- & 1 & 3 & 1 & Tr. \\
\hline Sillimanite------ & 1 & -- & -- & -- \\
\hline Andalusite------ & 6 & Tr. & -- & -- \\
\hline Staurolite------- & Tr. & Tr. & -- & -- \\
\hline Calcite-1-n- & $\mathrm{Tr}$. & Tr. & 2 & Tr. \\
\hline 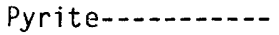 & -- & -- & Tr. & Tr. \\
\hline Apatite-n. & Tr. & Tr. & Tr. & Tr. \\
\hline Sphene---_-_--_- & -- & Tr. & Tr. & -- \\
\hline $\begin{array}{l}\text { Zircon } \\
\text { Thin sections }\end{array}$ & Tr. & -- & -- & -- \\
\hline $\begin{array}{l}\text { contributing } \\
\text { to average-..... }\end{array}$ & 11 & 7 & 3 & 5 \\
\hline
\end{tabular}

in small fractures. Crenulations, crinkles, and minor folds, characterized by parallel arrangement of biotite and muscovite flakes, are common.

Magnetite and quartz layer $(X \mathrm{~m})$. - The magnetite-quartz layer in the northern part of the schist unit is about $1.5 \mathrm{~km}$ long but less than $6 \mathrm{~m}$ thick. It consists of several thin alternating layers of magnetite and quartz interlayered conformably in schist. Each magnetitequartz layer is about $15 \mathrm{~cm}$ thick, but solid magnetite blocks (float) as much as $20 \mathrm{~cm}$ across have been found. The unit is poorly exposed. A syngenetic, metasedimentary origin (iron-formation) of the magnetite and quartz layer is suggested not only by its conformability, but also by the high $\mathrm{Mn}$ content ( $>5000 \mathrm{ppm}$ ) and relatively low Ti (500 ppm) and $\mathrm{Cr}(<10 \mathrm{ppm})$ content of the magnetite.

Quartzite $(X q)$.- The quartzite unit occurs in conformable lenslike bodies close to the transitional contact of hornblende gneiss and schist and in a much larger conformable lens in the northwest part of the hornblende gneiss. The quartzite is fine grained (average grain size $<1 \mathrm{~mm}$ ), is variable, and contains from about 60 to 95 percent quartz. Fine-grained biotite and muscovite flakes generally define a pronounced foliation. Each mapped quartzite lens is either all quartzite 
or is interfoliated with its host rock. Magnetite and hematite are common accessory minerals.

Hornblende gneiss (Xh).-The main body of hornblende gneiss occupies the central part of the map area. The northern contact of hornblende gneiss is transitional into granite gneiss, and the southern boundary is transitional into mica schist. Near the Schwartzwalder Mine on the northeast side of Ralston Creek, hornblende gneiss forms a salient that crosses the east branch of Roger's fault. This salient is interpreted to be the nose of the southward-plunging synform that provides the structural control of the Schwartzwalder deposit. Several smaller bodies of hornblende gneiss occur in the northern part of the map area. The hornblende gneiss is fine to medium grained (average grain size is $1 \mathrm{~mm}$ ). Hornblende, plagioclase, and quartz compose about 90 percent of the rock. Epidote is common locally. White, crystalline float blocks of marble as much as $30 \mathrm{~cm}$ across were seen in the northern outcrop area of the hornblende gneiss. Forms from 45 to $60 \mathrm{~cm}$ across, interpreted to be relict pillow lava, were noted in the east-central part of sec. 26 , T. 2 S., R. $71 \mathrm{~W}$., at the foliation symbol dipping $42^{\circ}$ to the west (pl. 1). The hornblende gneiss unit is probably volcanic in origin.

Granite gneiss (Xgg).-The granite gneiss unit occupies the eastcentral part of the map area. Its southern border is transitional into hornblende gneiss, and on its northern border granite gneiss merges with the interlayered granite gneiss and hornblende gneiss unit. A conspicuous feature of the transitional contact between granite gneiss and hornblende gneiss is the greater abundance of pegmatites than elsewhere. As shown on plate 1 , this zone is about $300 \mathrm{~m}$ wide. At several places in sec. 25 , T. 2 S., R. 71 W., granite gneiss occurs as conformable lenses in hornblende gneiss, where it is very fine grained and aplitic in texture. The granite gneiss is pink to pinkish gray and very fine to fine grained (average grain size $<1 \mathrm{~mm}$ ); more than 90 percent of the rock is composed of feldspar and quartz. Locally, biotite is sufficiently abundant to darken the rock perceptibly. Augen texture is developed along the transitional contact with hornblende gneiss, and it is well developed on Ralston Creek in the NW $1 / 4$ sec. 25, T. 2 S., R. $71 \mathrm{~W}$. A very high quartz content suggests a metasedimentary origin for the granite gneiss.

Granite gneiss and hornblende gneiss (Xggh).-This rock unit is composed of roughly equal parts of granite gneiss and hornblende gneiss, interfoliated complexly and having individual units from $1 \mathrm{~m}$ to $10 \mathrm{~m}$ thick. Consequently, separation of the two rock units is not practical at the map scale $(1: 12,000)$. The rock unit grades into granite gneiss to the south and into cataclastic granite gneiss of the Idaho Springs-Ralston shear zone to the northwest. The northeast strike 
of foliation in much of the granite gneiss and hornblende gneiss unit is interpreted to be the effect of cataclasis.

\section{CATACLASTIC ROCKS}

Granite gneiss (Xggc).-The cataclastic granite gneiss forms two northeast-trending zones in the northwest part of the map area. It is a pink to pinkish-gray, fine-grained (average grain size is $1 \mathrm{~mm}$ ) rock having a marked foliation that has resulted from granulation and shearing. In thin section, mortar structure and granulation are well developed. These cataclastic features are well defined in the cataclastic granite gneiss, but cataclasis also affects the granite gneiss and hornblende gneiss to the south as it gradually diminishes from north to south. Compositionally, the cataclastic granite gneiss is similar to the granite gneiss unit and is, therefore, interpreted as granite gneiss that has undergone cataclasis.

Biotite schist ( $\mathrm{Xbsc}$ ).- The cataclastic biotite schist unit in the northwest part of the map area occurs between zones of granite gneiss and hornblende gneiss. It is fine to medium grained and, in addition to abundant crinkled biotite, it commonly has small, pink porphyroblasts of feldspar. Felsic laminae are abundant locally. Mortar and flaser structures are especially evident in thin section.

\section{IGNEOUS AND METAIGNEOUS ROCKS}

Pegmatite $(X p)$.- Pegmatite occurs in almost all the Precambrian rock units, but it is most plentiful and widespread in the schist unit. Another zone of abundant pegmatite concentrate occurs in the general contact area between the hornblende gneiss and the granite gneiss. Almost all of the pegmatite bodies are lenslike and conformable, but a small number are crosscutting. The largest ones in the northwest part of the map area are complex in structure and contain septa of host rock. The pegmatites are coarse grained and consist mostly of microcline, perthite, quartz, and biotite with minor muscovite. Black tourmaline is a common accessory mineral; magnetite is less common. Apatite, chrysoberyl, columbite, and cleavelandite are uncommon minerals. The interpretation by Sheridan and others (1967) that many pegmatite bodies in the Ralston Buttes district are related to the Silver Plume Granite is strengthened by a potassium-argon age determination of 1,450 m.y. on muscovite from a pegmatite in the Schwartzwalder Mine (R. F. Marvin, H. H. Mehnert, and Violet Merrill, written commun., 1973). This 1,450-m.y. age determination may be either a primary age or a minimum age. The date correlates well with the 1,390- to $1,450-\mathrm{m} . \mathrm{y}$. ages of the Silver Plume and related granite obtained by Peterman and others (1968) using rubidium-strontium methods. 
Hornblende diorite and hornblendite (Xhd).-Several bodies of hornblende diorite and hornblendite occur in the northeastern part of the map area. Contacts with enclosing granite gneiss and hornblende gneiss are fairly abrupt. Grain size varies from fine to coarse $(<1 \mathrm{~mm}$ to $>1 \mathrm{~cm})$; hornblende and plagioclase $\left(\sim \mathrm{An}_{50}\right)$ compose most of the rock. Although more massive than surrounding granite gneiss and hornblende gneiss, the hornblende diorite shows a foliation that commonly is at right angles to that of the host rock. The relative massiveness of the hornblende diorite and hornblendite, in comparison to their host rock, probably protected their earlier impressed foliation and resisted the pervasive, northeast cataclasis that affected the host rock.

Quartz veins (Xqt).-Four massive quartz veins have been mapped in the schist unit. Most are conformable, but the one along the west branch of Rogers fault in the northern part of sec. 36, T. $2 \mathrm{~S} ., \mathrm{R}$. $71 \mathrm{~W}$., is nonconformable to host-rock foliation. The quartz is generally white and clean; it is fine to coarse in grain size $(<1 \mathrm{~mm}$ to $>1 \mathrm{~cm})$. The veins are as much as $2 \mathrm{~m}$ wide and attain lengths of as much as $30 \mathrm{~m}$.

\section{PALEOZOIC SEDIMENTARY ROCKS}

Pennsylvanian and Permian: Fountain Formation (PPf).-The Fountain Formation unconformably overlies Precambrian rocks in the eastern part of the map area as an eastward-dipping monocline; however, it is folded in secs. 30 and 31 , T. 2 S., R. 70 W., to form a syncline and anticline, both plunging southeast. The west limb of the anticline and the northern end of the syncline form a fault slice wedged between Precambrian rocks. The Fountain Formation consists of pink to reddish-orange arkosic sandstone and conglomerate and dark-reddish-brown mudstone and sandstone.

Permian: Lyons Sandstone (Ply).--The Lyons Sandstone occurs in the east-central part of the map area as part of a southeast-plunging syncline, where it lies conformably on the Fountain Formation. The Lyons Sandstone is a light-gray to grayish-orange, crossbedded, clean and well-sorted, fine- to medium-grained quartzose sandstone in the map area.

\section{TERTIARY INTRUSIVE ROCKS}

Mafic monzonite (Tmm).-A thin dike of severely altered mafic monzonite occurs in the northeast quarter of sec. 23, T. 2 S., R. $71 \mathrm{~W}$., and a similar dike occurs in the southeast quarter of the same section. Both dikes are probably outcrops of the same body and were intruded in late Laramide time. The one in the southeast quarter of sec. 23 is at least $1.2 \mathrm{~m}$ thick and has been traced for $46 \mathrm{~m}$. It strikes approximately N. $20^{\circ} \mathrm{W}$. and dips $20^{\circ} \mathrm{E}$. It intrudes granite 
gneiss and hornblendic rock, which shows segregations of marble as much as $30 \mathrm{~cm}$ across and large (several centimeters) hornblende crystals in vugs. Malachite occurs nearby in hornblendic rock. The dike rock is dark brown and has a pronounced spheroidal weathering. Fresh rock is aphanitic and markedly magnetic. A thin section of hard, relatively fresh rock shows an olive drab groundmass interspersed with small $(\sim 0.7 \mathrm{~mm})$ olive drab spheroids of chlorite, which are probably weathered remnants of olivine and augite, and an overall felty texture produced by abundant platy microlites of plagioclase $\left(\mathrm{An}_{52}\right)$. About one tenth of the rock consists of irregularly shaped potassic feldspar phenocrysts several millimeters in size, contributing a porphyritic aspect to the texture.

The dike in the northeast quarter of the same section has been traced for at least $170 \mathrm{~m}$, striking about $\mathrm{N} .5^{\circ} \mathrm{W}$. It dips east at approximately $55^{\circ}$ and is between 3 and $4 \mathrm{~m}$ thick. The dike is probably similar in composition to the Ralston dike, which is a mafic monzonite. Chemical and spectrographic analyses of the Ralston dike have been reported by Young (1979a).

\section{GENOZOIC SURFICIAL DEPOSITS}

\section{QUATERNARY DEPOSITS}

PLEISTOCENE, LOWER

Rocky Flats Alluvium (Qrf).-A small deposit of coarse, bouldery, cobble gravel is located on a grassy knoll in the west-central part of sec. 31, T. 2 S., R. 70 W. Because it consists largely of quartzite cobbles and boulders and lies at the same elevation as the Rocky Flats Alluvium mapped in the extreme northeast corner of the Ralston Buttes quadrangle by Sheridan and others (1967), it is interpreted to be that unit.

\section{PLEISTOCENE, UPPER}

Louviers Alluvium (Qlo).-Deposits of Louviers Alluvium in the southeastern part of the map area form grassy benches underlain by silty, fine-grained sand that is coarser at depth.

Broadway Alluvium ( $Q b)$.- The Broadway Alluvium in the southeastern part of the map area, as recognized by Sheridan and others (1967), is composed of silty, cobbly gravel and coarse sand.

\section{HOLOCENE}

Piney Creek Alluvium and post-Piney Creek alluvium (Qal).These two alluviums have not been differentiated. They are found along portions of Ralston Creek and its tributaries. 


\section{STRUCTURAL GEOLOGY}

\section{STRUCTURE OF PRECAMBRIAN ROCKS}

\section{FOLDING}

The major fold in the map area is expressed in mica schist, which is the country rock for the pitchblende-bearing fractures in the Schwartzwalder deposit (pl. 1). This fold is a steeply dipping synform that has an overturned west limb. Figure 3 is a contoured plot of poles to all the foliations (633) given on plate 1 . The poles form a girdle (great circle) whose perpendicular axis is a line striking S. $85^{\circ}$ W. and plunging $58^{\circ}$. This calculated line agrees well with the

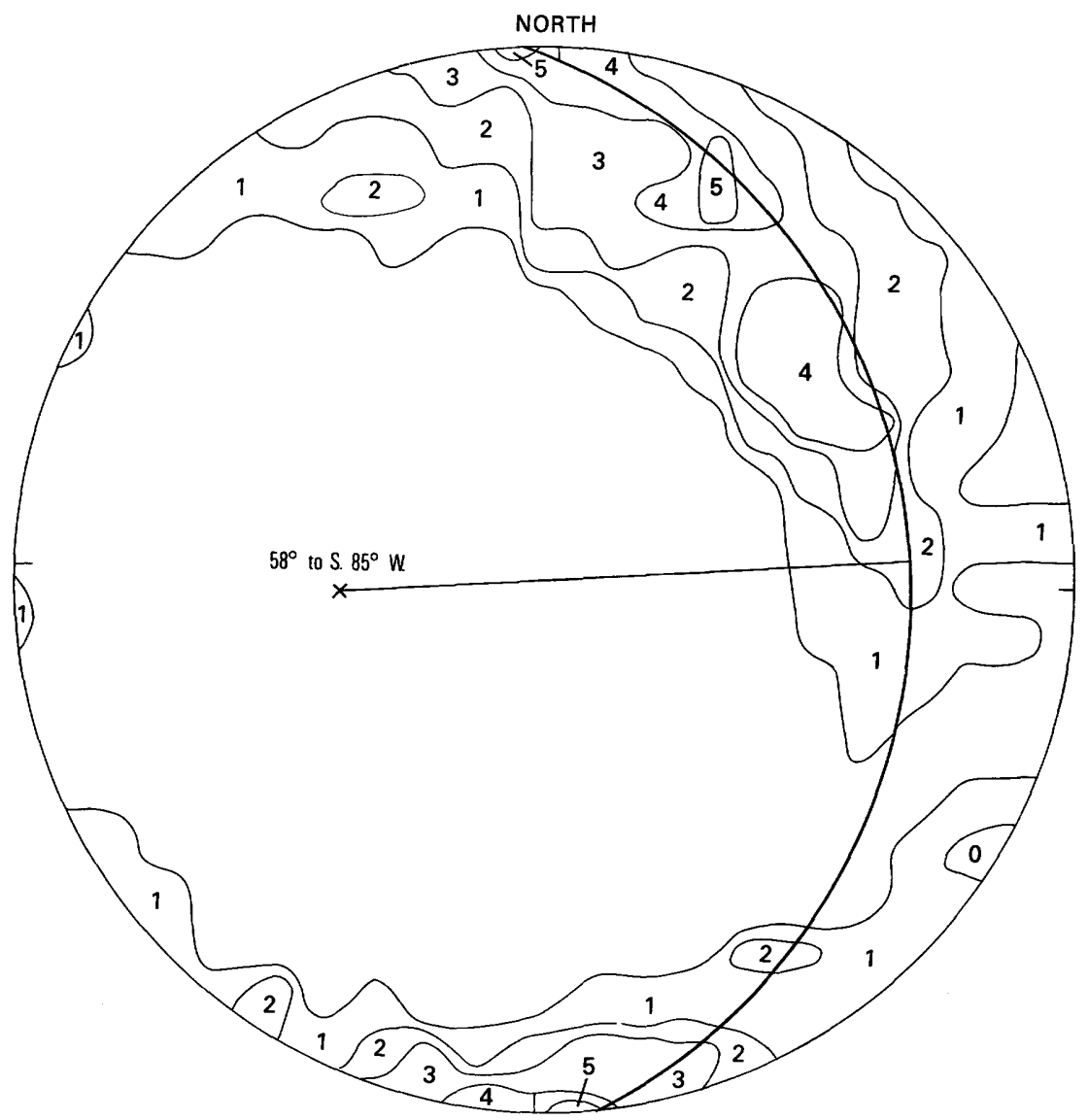

FIGURE 3.-Lower hemisphere projection of 633 poles to foliation on equal-area net, contoured in percent of poles per percent area. The poles form a girdle (great circle) whose perpendicular axis is a line striking $\mathrm{S}$. $85 \mathrm{~W}$. and plunging $58^{\circ}$. X marks the emergence of the perpendicular axis into the lower hemisphere. 
maximum concentration of 58 measured lineations shown in figure 4 . The northern portion of the synform manifests itself both on the surface and underground as a compressed tongue of schist containing garnetiferous zones and quartzite lenses. It evidently represents a compressed apical part of the synform, and by tracing its axis on the surface to the northeast its structure is shown by a tailing-out of the thin wedge of hornblende gneiss that encloses the schist tongue.

The quartzite body in the western part of the map area defines a minor southwest-plunging synform.

The general northwest-trending foliation of the granite gneiss becomes northeasterly to the north as a result of the shearing along the Idaho Springs-Ralston shear zone.

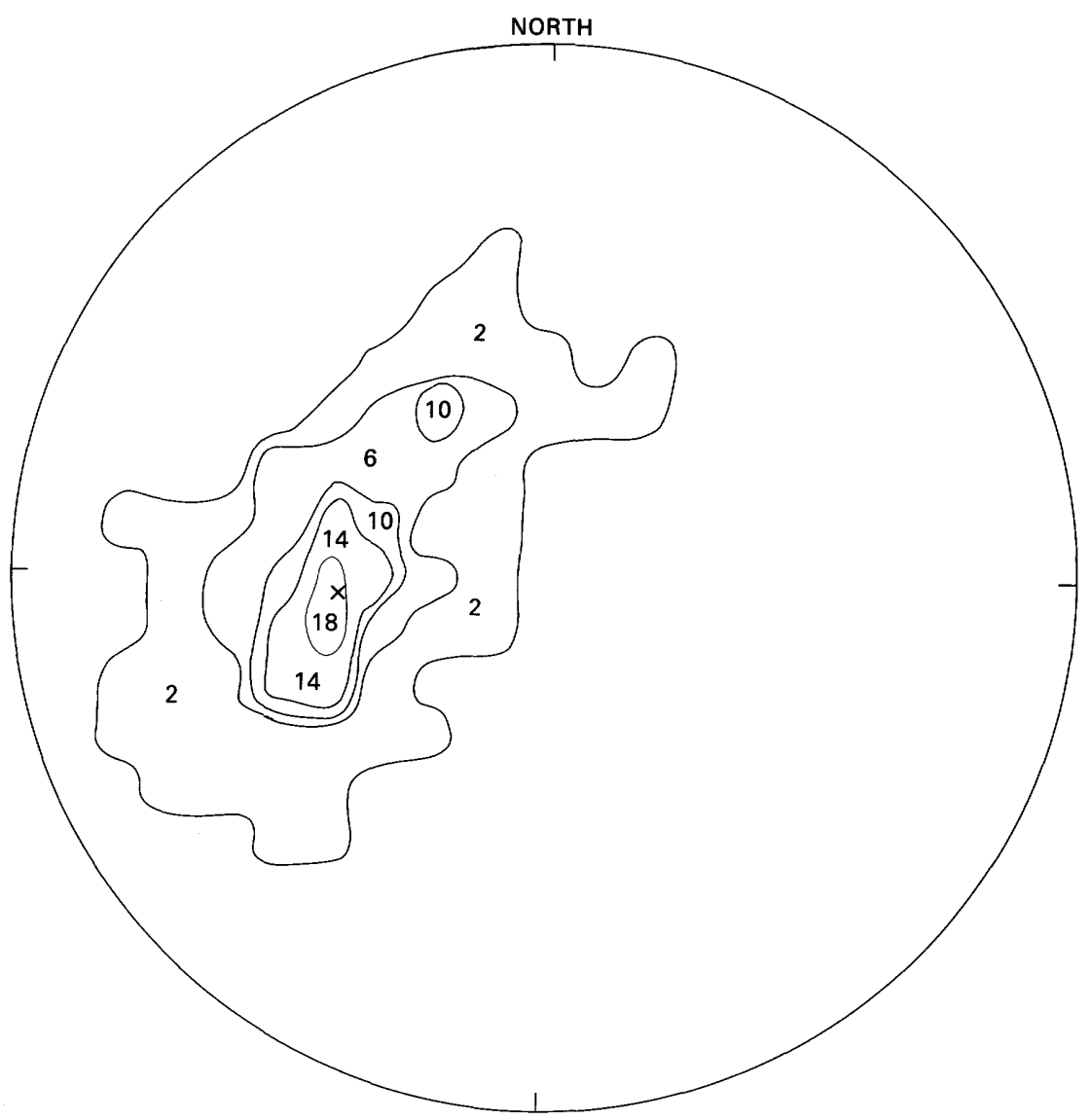

FIGURE 4.-Lower hemisphere projection of 58 lineations on equal-area net, contoured in percent of poles per percent area. $X$ marks the emergence of the perpendicular axis into the lower hemisphere. 


\section{IDAHO SPRINGS-RALSTON SHEAR ZONE}

This distinctive structural zone, formed after Precambrian folding and located in the northwest part of the map area, was named and discussed by Tweto and Sims (1960; 1963, p. 998-1000). The intense shearing, as indicated by the cataclastic granite gneiss and the cataclastic biotite schist within the zone, is also evident in the granite gneiss and hornblende gneiss that lie to the south of it.

\section{BRECCIA REEFS}

The northern half of the map area contains a set of parallel to subparallel, northwest-trending fracture zones called breccia reefs and breccia dikes (Lovering and Goddard, 1950, p. 79). These late Precambrian fracture zones may be faults of indeterminate or small displacement, and they are characterized by steep dips and breccia zones as much as $100 \mathrm{~m}$ wide. Their usual surface expression is a rubble of loose, yellow-brown altered rocks, but locally is a wall-like outcrop of resistant breccia, such as the one in the SE $1 / 4$ sec. 25, T. 2 S., R. $71 \mathrm{~W}$., which has an approximate dip of $75^{\circ}$ to the east. The breccia weathers to a rough surface on which fragments of wall rock, ankerite, potassic feldspar, and quartz stand out in relief. More commonly, where breccia reefs cross ridges, the site is marked by a topographic depression or saddle. Positive or negative relief of the breccia reefs is generally a function of silicification. Actual observed sites of breccia outcrop or rubble are marked in plates 1 and 2 . The breccia reef $200 \mathrm{~m}$ northeast of the east branch of Rogers fault is also marked by two springs.

The relative displacement along the breccia reefs in the map area is insignificant megascopically, and hence, as mentioned by Sheridan and others (1967, p. 70-71), the term fracture zone is more appropriate than fault. Apparent lateral movement on the east and west branches of Rogers fault is negligible, because the hornblende gneiss is not displaced where it crosses the east branch (fig. 5), and the magnetite and quartz layer is not displaced where it crosses the west branch. Vertical movement on the east branch is also probably small. Sheridan and others (1967) indicated an apparent horizontal displacement of $670 \mathrm{~m}$ on the east branch, but if my interpretation of a fold in the Fountain Formation is correct, there is no appreciable horizontal displacement.

\section{OTHER FAULTS}

Two other kinds of faults in the Schwartzwalder area differ sufficiently from the breccia reefs to merit separate mention. The first of these is the Illinois fault, which is the main vein of the Schwartzwalder deposit; it is persistent underground, but not as long or as wide 


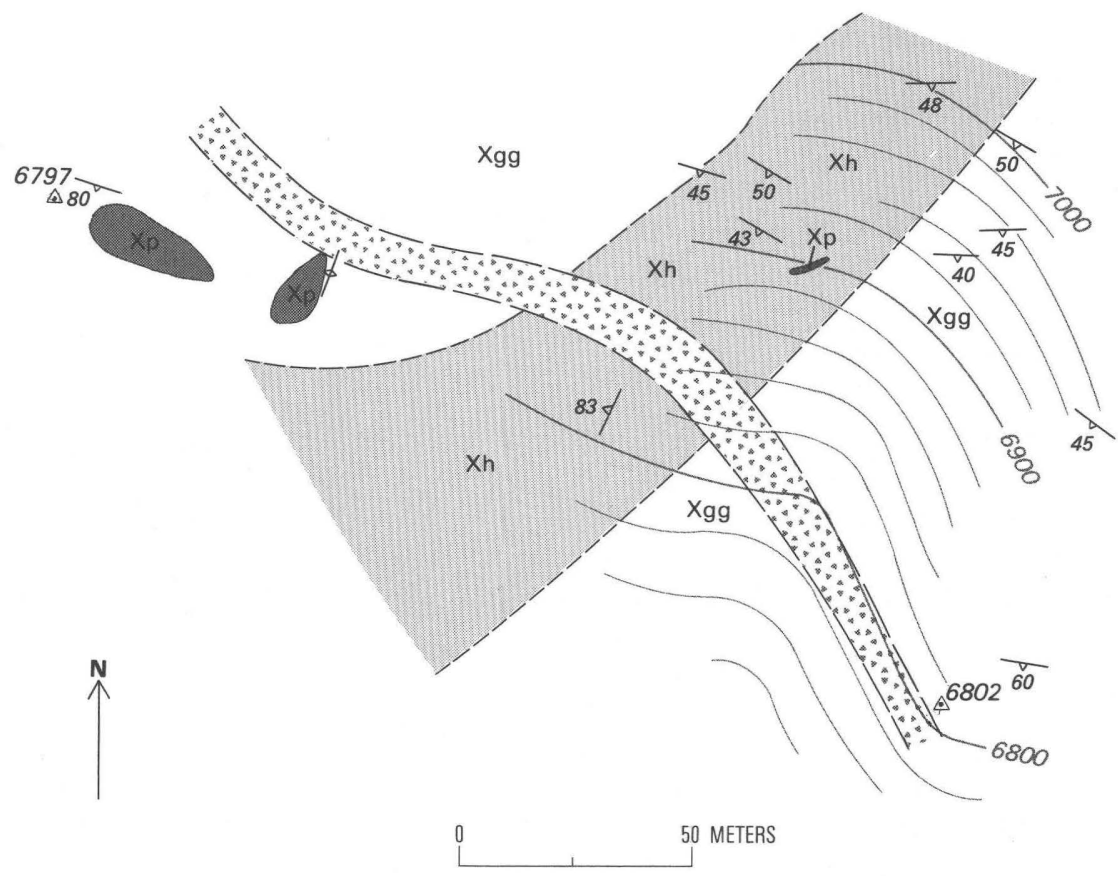

EXPLANATION

\begin{tabular}{|c|l}
\hline $\mathrm{Xgg}$ & Pegmatite \\
\cline { 1 - 1 } & $\begin{array}{l}\text { Granite gneiss } \\
\text { Hornblende gneiss }\end{array}$ \\
\cline { 1 - 1 } & $\begin{array}{c}\text { Breccia of east branch } \\
\text { of Rogers fault }\end{array}$ \\
\hline
\end{tabular}

\begin{tabular}{ll}
$\triangle$ & Triangulation point \\
$\frac{45}{4}$ & $\begin{array}{c}\text { Strike and dip of foliation } \\
\text { Inclined }\end{array}$ \\
6802 & Vertical \\
\hline- & Elevations in feet
\end{tabular}

Figure 5.-Plane table map of critical area in $\mathrm{SE}^{1 / 4} \mathrm{sec}$. 25, T. $2 \mathrm{~S} ., \mathrm{R} .71 \mathrm{~W}$., where hornblende gneiss crosses east branch of Rogers fault with no apparent displacement. Topography and geology by Kenneth Segerstrom and E. J. Young, 1975.

as the breccia reefs. It dips steeply (about 75 degrees) to the west and forms a cymoid of the following character: its southeast extremity strikes northwest; its middle, ore-bearing portion strikes north, in conformity with its schist host; and its northwest extremity turns northwest and probably follows the valley of Ralston Creek. Observed displacements in the Illinois fault are not large $(<2 \mathrm{~m})$, and conflicting evidence of movement in the fault suggests that movement was probably recurrent and in different directions. The Washington fault, about $40 \mathrm{~m}$ to the east, is the same type of fault, but is much smaller.

The second type of fault is represented by northeastward-dipping fractures on the hanging wall side of the Illinois fault. Some of these 
intersect the surface, but other deeper ones do not. These faults are generally narrow wrench or shear faults showing the least displacement of the three types of faults. Most, if not all, of their movement probably occurred in Laramide time.

\section{FOLDS AND FAULTS IN PALEOZOIC ROCKS}

The Laramide orogeny caused folding in the Paleozoic rocks and rejuvenated faults in the northwest-trending breccia reefs.

The Fountain Formation and the Lyons Sandstone are folded into a southeast-plunging syncline in the east-central part of the map area. This folding buckled the Fountain Formation around the granite gneiss bulwark and resulted in a fault slice between two Precambrian blocks. Renewed Laramide movement on the east branch of Rogers fault may have further displaced the fault slice.

\section{RADIOMETRIC AND MINERALOGIC DATA}

A radiometric survey covering the map area was done using a handheld scintillometer (Mount Sopris Instrument Company, Model SC-131) containing a $3.8 \times 3.8-\mathrm{cm}$ crystal detector. ${ }^{1}$ The readings are expressed in counts per second (cps) and are shown on plate 2 . To evaluate counts per second in terms of equivalent uranium (eU), the following approximate relation may be used: $5 \mathrm{cps}=1 \mathrm{ppm}$ as derived from analyzed rocks. The term $\mathrm{eU}$ represents the summation of radioactivity from the rock and does not discriminate between contributions from uranium, thorium, and potassium.

Relatively high readings from veins and other hot spots, shown on plate 2, are almost entirely due to uranium and its daughter products. As may be seen from plate 2 and table 2 , each rock unit has characteristic radiometric readings; and, therefore, radiometry may sometimes be an aid in differentiating rock types in the field whenever such rock tends to be nondescript due to very fine grain size, alteration, or tectonic strain.

Mineralogic data of various kinds are shown on plate 2. Malachite distribution, indicating copper, is mòstly confined to breccia reefs. Some pegmatites within the mica schist contain apatite, columbite, and chrysoberyl. Coarsely crystalline tourmaline (schorl) is common to pegmatites in all rock types, but fine-grained tourmaline was only noted in pegmatites within the schist. The distribution of metamorphic minerals - staurolite, andalusite, sillimanite, and garnet-is shown in the schist.

\footnotetext{
${ }^{1}$ Use of this brand name is for descriptive purposes only and does not constitute endorsement by the U.S. Geological Survey.
} 
TABLE 2.-Scintillometer readings in counts per second of rocks in the Schwartzwalder area

\begin{tabular}{|c|c|c|c|}
\hline & \multicolumn{2}{|c|}{ Counts per second } & \multirow{2}{*}{$\begin{array}{l}\text { Number of readings } \\
\text { contributing to average }\end{array}$} \\
\hline & Average & Range & \\
\hline Vein quartz- & 55 & $50-60$ & 3 \\
\hline Hornblende diorite- & 55 & $40-.85$ & 15 \\
\hline Quartzite- & 57 & $35-180$ & 11 \\
\hline Lyons Sandstone- & 65 & 65 & 2 \\
\hline Hornblende gneiss & 65 & $15-160$ & 183 \\
\hline Mafic monzonite- & 70 & 70 & 1 \\
\hline Magnetite and quartz-......... & 90 & 90 & 1 \\
\hline Pegmatite & 131 & $75-275$ & 92 \\
\hline Aplite in nornblende gneiss-- & 175 & $120-300$ & 5 \\
\hline Biotite schist, cataclasized & 179 & $140-230$ & 13 \\
\hline Schist-- & 181 & $120-290$ & 286 \\
\hline Granite gneiss, cataclasized & 195 & $140-290$ & 18 \\
\hline Fountain Formation- & 242 & $150-360$ & 32 \\
\hline Granite gneiss- & 255 & $160-440$ & 90 \\
\hline $\begin{array}{l}\text { Fault breccia (in } \\
\text { nornblende gneiss) } \\
\end{array}$ & 112 & $55-205$ & 16 \\
\hline Fault breccia (in & & & \\
\hline granite gneiss) & 221 & $155-300$ & 10 \\
\hline Fault breccia (in schist)---- & 225 & $155-320$ & 6 \\
\hline
\end{tabular}

\section{ECONOMIC GEOLOGY}

\section{SCHWARTZWALDER MINE}

The Schwartzwalder is the most productive uranium vein deposit in the United States. To date, about 5 million $\mathrm{kg} \mathrm{U}_{3} \mathrm{O}_{8}$ (11 million pounds) has been produced, which represents about 97 percent of the uranium mined from the Front Range. Ultimate production may be more than twice that amount.

In this section only a brief resume is given. The following reports should be consulted for more detail: Downs and Bird (1965), Sheridan and others (1967), Derzay and Bird (1976), and Young (1977, 1979a, and $1979 b)$.

The Schwartzwalder deposit, named for Fred Schwartzwalder, who discovered its uranium potential in 1949 , was known as a copper prospect before its uranium potential was discovered. In 1953 the first ore shipments were made by Mr. Schwartzwalder, and in 1956 the Denver-Golden Oil and Uranium Company purchased the property. In 1965 the Cotter Corporation acquired the property, and in 1974 the Cotter Corporation became the wholly owned subsidiary of Commonwealth Edison Company.

The structural framework for the deposit is defined by a fracture system that provided an abundance of openings for infiltration by uranium-bearing solutions. The deposit is bounded on the northeast and southwest by northeastward-dipping $\left(\sim 75^{\circ}\right)$ breccia reefs of the Ro- 
gers system. Lying about midway between the breccia reefs is the cymoid Illinois fault. The Illinois fault strikes north through the productive part of the mine area, but at its extremities bends to a northwest strike. Unlike the breccia reefs, it dips westerly $\left(\sim 75^{\circ}\right)$. The Illinois fault, mineralized along most of its fracture or fault plane, composes the main vein. Mineralized horsetail fractures dip into the Illinois on the hanging wall side. Surrounding the north-striking plane of the Illinois fault is a tightly compressed fold of quartzose schist, garnetiferous schist, and quartzite lenses. The rock in the trough of the compressed fold was favorable for ore emplacement because it was extensively fractured as a result of Laramide stress. The abundant pegmatites in the transition zone between hornblende gneiss and schist, shown on plate 1 , contributed to the intense fracturing because of the inhomogeneity they provided during tectonic strain. The enclosing hornblende gneiss displays fractures that are tightly healed by calcite.

The ore deposit is entirely fracture-controlled. Pitchblende, the predominant ore mineral, is confined to vein fissures and their breccia zones; it is accompanied by pyrite and minor amounts of sulfides such as galena, jordisite, molybdenite, and sphalerite. The most reliable age determinations made on the pitchblende mineralization, using ${ }^{206} \mathrm{~Pb} /{ }^{238} \mathrm{U}$ ratios, average around $60 \mathrm{~m} . \mathrm{y}$. (Marvin and others, 1974). Support for the 60-m.y. age is given by an entirely different method, using fission tracks in apatite. C. W. Naeser (written commun., 1976) reported a weighted age (according to number of tracks counted) of $62.4 \pm 2.2 \mathrm{~m}$.y. for four accessory apatites from veins and from the vicinity of veins. According to Naeser, $62.4 \mathrm{~m}$.y. represents the last time the rocks cooled below about $110^{\circ} \mathrm{C}$.

Table 3 shows the distribution and concentration of elements in the Schwartzwalder deposit (Young, 1979b) relative to crustal abundance. Of the seven elements besides uranium that are enriched much more than one hundred times crustal abundance, four (molybdenum, antimony, tungsten, and thallium) are high-valent constituents of uraniumbearing solutions that were entrapped in the formation of colloidal pitchblende. Silver and lead occur in widespread galena.

Pitchblende from many vein deposits worldwide is low in rare earth elements and thorium, but high in metals such as molybdenum, antimony, and tungsten. On the other hand, uraninite from pegmatites is high in rare earth elements and thorium, and low in metals such as molybdenum, antimony, and tungsten. This contrast in chemistry between uraninite from pegmatites and pitchblende from veins is shown by 43 analyses listed by Frondel (1958, p. 16-20). Some of the analyses listed as uraninites in Frondel's tabulation are almost certainly pitchblende (his analyses $21,30,37,42$, and 43 ). In almost 
TABLE 3.-Distribution and concentration of elements, relative to crustal abundance, in Schwartzwalder pitchblende ore

[Modified from Young, 1979b; n.d., not determined]

\begin{tabular}{|c|c|c|c|c|}
\hline Element $^{1}$ & $\begin{array}{l}\text { Number of samples } \\
\text { contributing to } \\
\text { average }\end{array}$ & $\begin{array}{l}\text { Average } \\
\text { percent }\end{array}$ & $\begin{array}{l}\text { Crustal abundance }{ }^{2} \\
\text { in percent }\end{array}$ & $\begin{array}{c}\text { Enrichment factor } \\
=\text { average/crustal } \\
\text { abundance }\end{array}$ \\
\hline $\begin{array}{l}U \\
\text { Mo } \\
\text { Sb } \\
W \\
B i\end{array}$ & $\begin{array}{l}42 \\
42 \\
41 \\
42 \\
42\end{array}$ & $\begin{array}{c}17.67 \\
.53 \\
.11 \\
.15 \\
<.001\end{array}$ & $\begin{array}{l}0.00025 \\
.00011 \\
.00005 \\
.00013 \\
.0000009\end{array}$ & $\begin{array}{r}70,700 \\
4,800 \\
2,200 \\
1,150 \\
<1,000\end{array}$ \\
\hline $\begin{array}{l}\mathrm{Pb} \\
\mathrm{As} \\
\mathrm{Ag} \\
\mathrm{Tl} \\
\mathrm{Hg}\end{array}$ & $\begin{array}{r}42 \\
42 \\
41 \\
21 \\
2\end{array}$ & $\begin{array}{l}.96 \\
<.1 \\
.0029 \\
.04 \\
>.001\end{array}$ & $\begin{array}{l}.0016 \\
.00017 \\
.000007 \\
.0001 \\
.0000083\end{array}$ & $\begin{array}{r}600 \\
<590 \\
410 \\
400 \\
>120\end{array}$ \\
\hline $\begin{array}{l}\mathrm{Se} \\
\mathrm{S} \\
\mathrm{Zn} \\
\mathrm{Cu} \\
\mathrm{Zr}\end{array}$ & $\begin{array}{r}2 \\
2 \\
42 \\
42 \\
42\end{array}$ & $\begin{array}{l}.00037 \\
2.0 \\
.26 \\
.077 \\
.135\end{array}$ & $\begin{array}{l}.000005 \\
.047 \\
.0083 \\
.0047 \\
.017\end{array}$ & $\begin{array}{r}74 \\
43 \\
30 \\
16 \\
8\end{array}$ \\
\hline $\begin{array}{l}\mathrm{Nb} \\
\mathrm{Be} \\
\mathrm{Co} \\
\mathrm{Y} \\
\mathrm{V}\end{array}$ & $\begin{array}{r}42 \\
30 \\
5 \\
8 \\
42\end{array}$ & $\begin{array}{l}.009 \\
.0015 \\
.006 \\
.0079 \\
.028\end{array}$ & $\begin{array}{l}.002 \\
.00038 \\
.0018 \\
.0029 \\
.009\end{array}$ & $\begin{array}{l}5 \\
4 \\
3 \\
3 \\
3\end{array}$ \\
\hline $\begin{array}{l}\mathrm{Yb} \\
\mathrm{Mn} \\
\mathrm{Ni} \\
\mathrm{Ca} \\
\mathrm{K}\end{array}$ & $\begin{array}{l}30 \\
30 \\
41 \\
30 \\
30\end{array}$ & $\begin{array}{l}<.0001 \\
.22 \\
.012 \\
4.32 \\
3.0\end{array}$ & $\begin{array}{l}.000033 \\
.1 \\
.0058 \\
2.96 \\
2.5\end{array}$ & $\begin{array}{l}<3 \\
2 \\
2 \\
1.5 \\
1.2\end{array}$ \\
\hline $\begin{array}{l}\mathrm{B} \\
\mathrm{La} \\
\mathrm{Fe} \\
\mathrm{F} \\
\mathrm{Sc}\end{array}$ & $\begin{array}{r}28 \\
42 \\
30 \\
2 \\
31\end{array}$ & $\begin{array}{l}.001-.002 \\
<.005 \\
4.84 \\
.063 \\
.001\end{array}$ & $\begin{array}{l}.0012 \\
.0029 \\
4.65 \\
.66 \\
.001\end{array}$ & $\begin{array}{l}1 \\
1 \\
1 \\
1 \\
1\end{array}$ \\
\hline $\begin{array}{l}\mathrm{Ga} \\
\mathrm{Sr} \\
\mathrm{Mg} \\
\mathrm{Ti} \\
\mathrm{Al}\end{array}$ & $\begin{array}{r}5 \\
30 \\
30 \\
30 \\
30\end{array}$ & $\begin{array}{l}.0015 \\
.02 \\
1.12 \\
.2 \\
3.1\end{array}$ & $\begin{array}{l}.0019 \\
.034 \\
1.87 \\
.45 \\
8.05\end{array}$ & $\begin{array}{l}0.8 \\
.6 \\
.6 \\
.4 \\
.4\end{array}$ \\
\hline $\begin{array}{l}\mathrm{Cr} \\
\mathrm{Ba} \\
\mathrm{Si} \\
\mathrm{Na} \\
\mathrm{Au}\end{array}$ & $\begin{array}{r}42 \\
30 \\
8 \\
5 \\
42\end{array}$ & $\begin{array}{l}.003 \\
.021 \\
2->10 \\
.1^{3} \\
\text { n.d. }\end{array}$ & $\begin{array}{l}.0083 \\
.065 \\
29.5 \\
2.5 \\
.0000004\end{array}$ & $\begin{array}{l}.4 \\
.3 \\
.07->0.3 \\
.04\end{array}$ \\
\hline
\end{tabular}

${ }^{1}$ Most elements were determined spectrographically. Seven of the $I J$ analyses were done fluorometrically. Four of the $W$ analyses were done using a spectrophotometric isotope dilution method. $\mathrm{Hg}$, Se, and $\mathrm{S}$ were determined instrumentally, fluorometrically, and titrametrically, respectively. F was determined using an ion electrode method. The following elements, with their detection limits (ppm) shown in parentheses, were looked for and not found: $\mathrm{Ce}(200)$, Nd (70), Sn (10), and Th (200).

2 Vinogradov (1962).

${ }^{3}$ Sheridan and others $(1967, p .100)$ reported traces of Au in 3 out of 30 channel samples. 
all cases the difference between uraninite and pitchblende is unambiguous. Although both are mineralogically uraninite, genetic differences are blurred by classing them both as uraninite. Uraninite is macrocrystalline, usually shows good crystal form, and originates at high temperature, whereas pitchblende is microcrystalline, is usually colliform, and originates at relatively low temperature.

The Schwartzwalder deposit represents a unique set of geologic circumstances, which consist of structural complexity, nearby source rocks containing uranium, and a magmatic heat source (Young, 1979b). The absence of any one circumstance, and especially of two, would greatly diminish or eliminate chances for formation of a pitchblende vein deposit of this magnitude. Small uranium deposits and occurrences abound in this general area (Sims and Sheridan, 1964), but none approaches the Schwartzwalder deposit in economic importance. I contend that one or more of the aforementioned circumstances are missing from the small deposits and occurrences and that the Schwartzwalder probably is unique.

Figure 6, taken from Young (1979b), illustrates a possible sequence of events leading to formation of the deposit. This interpretation is consistent with the fact that the age of the intrusion (approximately 62 m.y.) is similar to the age of the deposit (approximately 60 m.y.).

\section{MENA MINE}

Mena is the Spanish word for ore, hence Mena Mine or Ore Mine. The first discovery of pitchblende in the Ralston Buttes district was made by Fred Schwartzwalder in 1949 at the Mena Mine, formerly known as the Hoffmeister copper prospect. Access to the mine workings, now abandoned, consists of two shafts and three adits. Sparse literature on the mine is found in reports by Adams and others (1953), Sims and Sheridan (1964), Sheridan and others (1967), and Derzay and Bird (1976). Walker and Adams (1963) illustrated ore from the Mena.

The Mena Mine is located in the north-central part of sec. 26, T. 2 S., R. 71 W. (pl. 1). Production from the mine from 1956 to 1960 was approximately $2470 \mathrm{~kg} \mathrm{U} \mathrm{U}_{3} \mathrm{O}_{8}(5430 \mathrm{lbs})$. Ore tenor averaged 0.27 percent $\mathrm{U}_{3} \mathrm{O}_{8}$.

The Mena vein is a mineralized breccia in a fault of the Rogers system. The fault strikes north-northwest and dips moderately to steeply northeast. Wallrocks are hornblende gneiss interlayered with minor biotite gneiss, but the granite gneiss unit lies only approximately $60 \mathrm{~m}$ to the northeast.

The mineralized breccia contains a network of thin veinlets of pitchblende in a mass of sulfide and other metallic minerals, and gangue, including low-temperature potassic feldspar (Sheridan and others, 


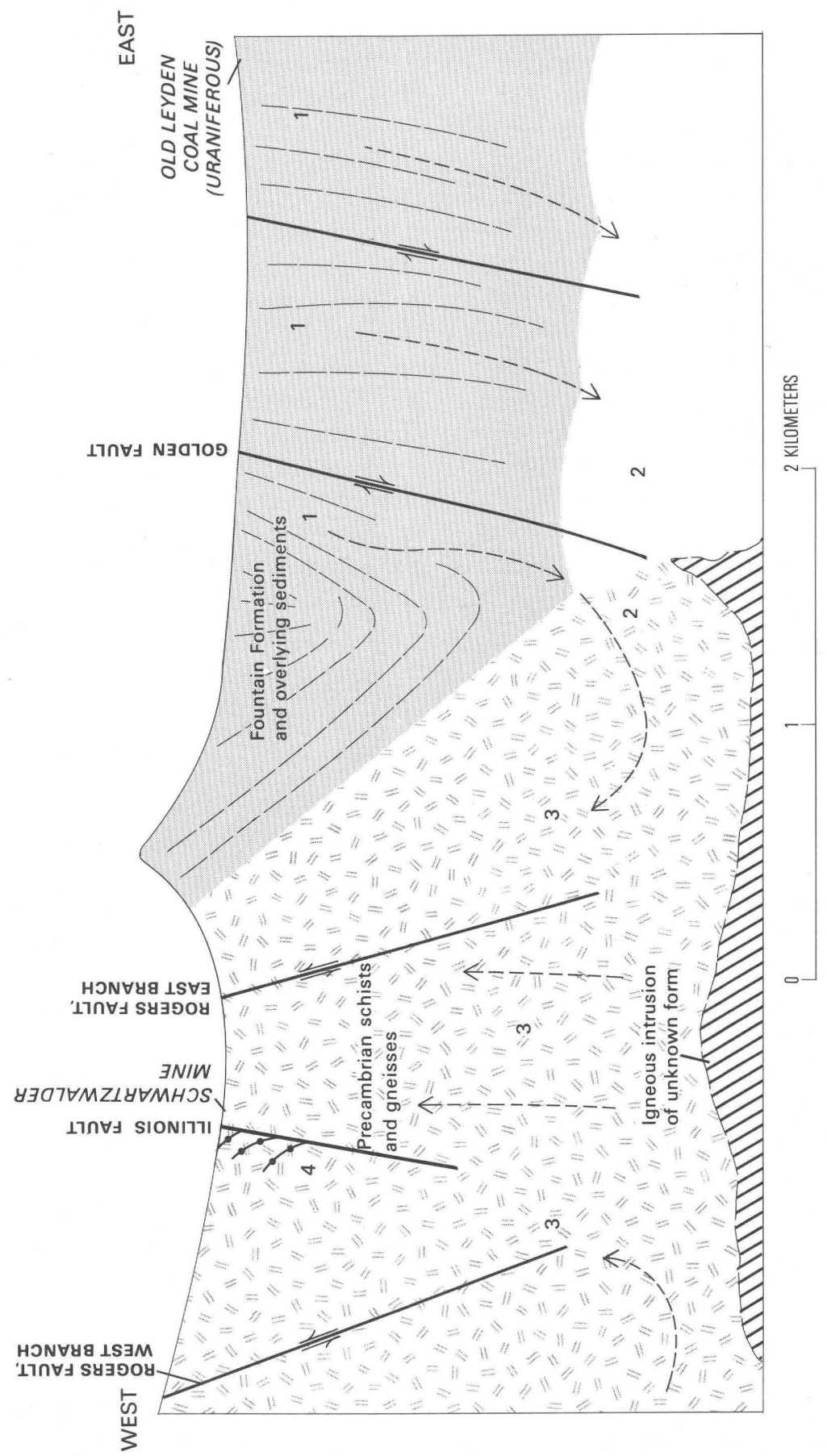


1967, p. 80), ankerite, quartz, and calcite. The pitchblende occurs as thin $(\sim 0.5 \mathrm{~mm})$ coatings on breccia fragments. Other ore minerals recorded by Sheridan and others (1967) are "hydropitchblende," chalcopyrite, pyrite, tetrahedrite-tennantite, chalcocite, bornite, galena, native bismuth, native copper, native silver $^{1}$, niccolite, pararammelsbergite?, maucherite?, covellite, and secondary copper minerals. The paragenetic sequence of mineralization seems to be, from oldest to youngest, potassic feldspar, ankerite, pitchblende, quartz, ankerite, calcite, sulfides, native metals, and sulfosalt minerals.

Two analyses of ore from the Mena, shown in table 4, indicate that five elements, bismuth, silver, arsenic, antimony, and copper, are concentrated more than uranium in this deposit. Although this deposit cannot strictly be compared to the Schwartzwalder deposit because of the great difference in magnitude, it would seem to be fundamentally different from the point of view of geochemistry. Sims and Sheridan (1964) classified the Mena as a class 3 deposit (veins in which uranium minerals are dominant), but analyses available so far would place the deposit in class 2 (uranium-bearing base-metal sulfide veins).

Sheridan and others (1967) reported a radiometric age of $73 \pm 5$ m.y. for the pitchblende at the Mena. These ratios and ages are as follows:

$$
\begin{aligned}
& { }^{206} \mathrm{~Pb} /{ }^{238} \mathrm{U}: 73 \pm 0.2 \mathrm{~m} . \mathrm{y} . \\
& { }^{207} \mathrm{~Pb} /{ }^{235} \mathrm{U}: 7361.7 \mathrm{~m} . \mathrm{y} . \\
& { }^{207} \mathrm{~Pb} /{ }^{206} \mathrm{~Pb}: 66 \pm 57 \mathrm{~m} . \mathrm{y} .
\end{aligned}
$$

\section{NORTH STAR MINE}

The North Star Mine, which consisted of a short upper level and a lower adit connected with a stope that opened to the surface, is no longer accessible. When visited in October 1973, a road had been bulldozed over the workings, but copper-uranium ore was present on the dump of the former mine and scintillometer readings were over

${ }^{1}$ Wire silver as much as several millimeters long in late, vuggy calcite was collected by the author in 1973.

Figure 6 (facing page).-Diagrammatic cross section through the Schwartwalder deposit illustrating sequence of events leading to uranium deposition. Vertical and horizontal scales are the same. (1) Surface water enters steeply dipping sedimentary rocks and dissolves uranium from preexisting deposits or disseminations. (2) Descending uraniumbearing solutions are heated at depth by a Laramide igneous intrusion (the source of the nearby Ralston dike). (3) A convective pattern of water flow, caused by the intrusion, draws water from the sedimentary rocks (and also from rocks west of the Schwartzwalder deposit) and causes it to rise toward the surface along the Illinois fault and other faults. (4) With decrease in pressure and temperature, pitchblende is deposited in available openings. 
TABLE 4.-Distribution and concentration of elements, relative to crustal abundance, in two ore samples from the Mena Mine

[See table 3. Spectrographic analyses by R. G. Havens (sample N-1) and L. A. Bradley (sample RC-157A), except as noted]

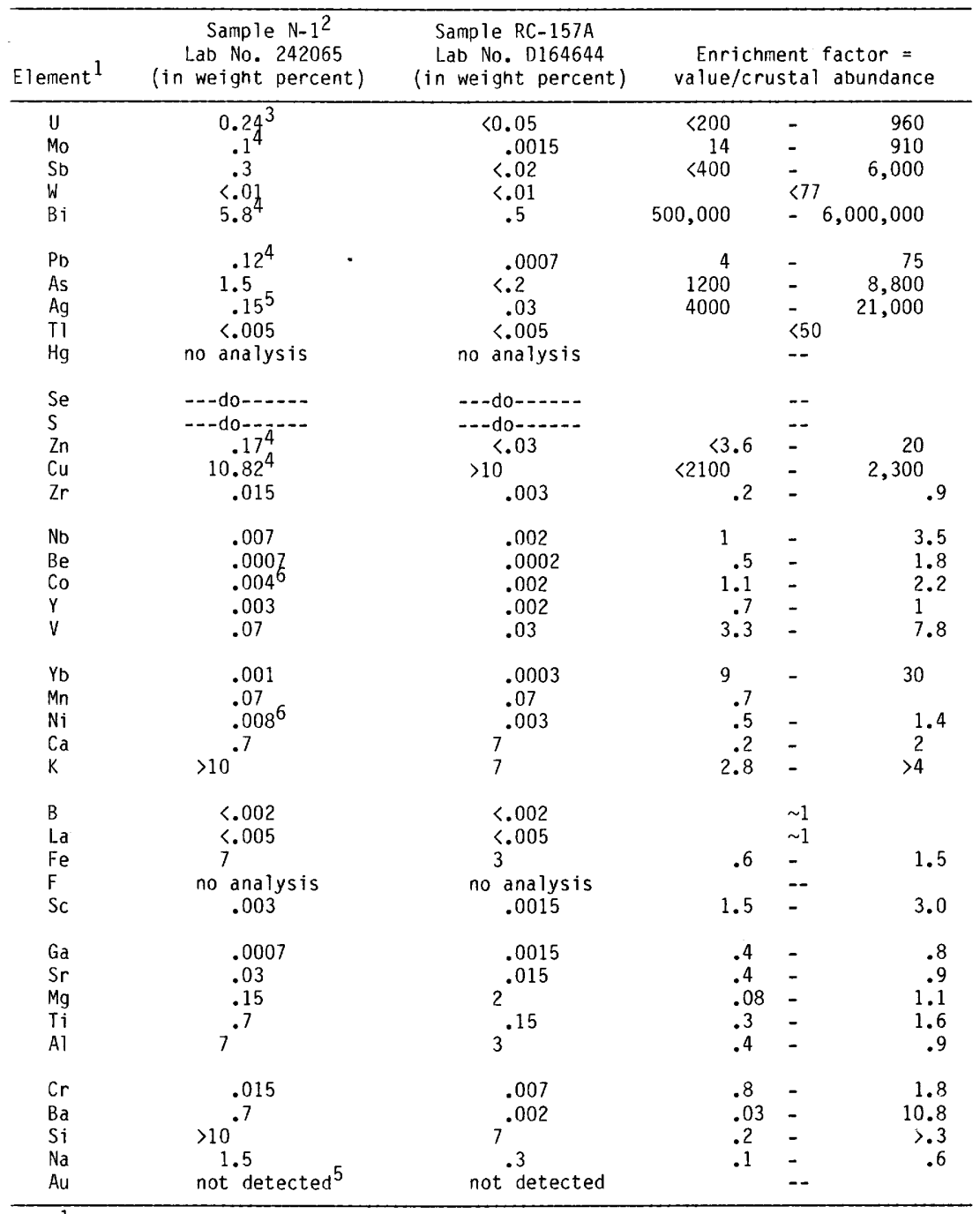

${ }^{1}$ The following elements (with detection limits, ppm, in parentheses) were looked for and not found: Cd (50), Ce (200), Eu (100), Ge (10), Hf (100), In (10), $\mathrm{Li}(100)$, Nd (70), P (2000), Pd (2), Pt (50), Re (50), Sn (10), Ta (500), Te (2000), and Th (200).

${ }^{2}$ Sneridan and others (1967, p. 81).

3 Analyst, J. S. Wahlberg. Analytic method: $U$, volumetric.

${ }^{4}$ Analyst, W. D. Goss. Analytic method: Bi, gravimetric; $\mathrm{Cu}$, electrolytic; Mo, colopimetric; $\mathrm{Zn}$ and $\mathrm{Pb}$, volumetric.

Analyst, D. L. Skinner. Analytic method: Ag and Au, fire assay.

6 Analysts, Claude Huffman, Jr., and R. F. Dufour. Analytic method: Co and $\mathrm{Ni}$, colorimetric. 
2000 cps. About 16 tons of copper ore was produced by 1916 , but not until April 1952 was pitchblende discovered at the mine by Adams and others (1953).

The site is close to the center of the $\mathrm{SE}^{1 / 4}$ sec. $23, \mathrm{~T} .2 \mathrm{~S} ., \mathrm{R}$. $71 \mathrm{~W}$., in the rock unit mapped as interlayered granite gneiss and hornblende gneiss. Foliation in the mine area strikes northeast and is about vertical. The mine is also located on and near the north end of one of the northwest-trending fractures of the Rogers system. This fracture can be traced for at least $1.3 \mathrm{~km}$ and also passes through two springs and three copper-uranium prospects shown on plate 1 .

Mineralized breccia forms a vein dipping $25^{\circ}-45^{\circ}$ northeast at the mine (Adams and others, 1953). It is perhaps significant that the only Tertiary intrusive igneous rock in the whole map area lies within 60 $m$ of this fracture and has a roughly parallel attitude.

According to Adams and others (1953), uranium and copper minerals occur sporadically throughout the vein as fracture fillings and as interstitial material surrounding breccia fragments. Ore minerals are bornite, chalcocite, covellite, malachite, azurite, pitchblende, "hydropitchblende," uranophane, and several unidentified uranium minerals. Besides the rock breccia fragments, carbonate, potassic feldspar, and hematite staining constitute the gangue.

Table 5 gives analytic data on the ore, and the element enrichment factors indicate that ore from the North Star Mine is very similar to that of the Mena.

\section{OTHER PROSPECTS}

The six other prospects, described in this section and shown on plate 1, are minor and show geochemical affinities to the Mena and North Star Mines. All of the prospects are unnamed and have been given numbers from 4 to 9 for ease of reference. They were all visited by the writer in the latter part of 1973 . Table 6 shows the results of a grab sample analysis from each prospect.

Prospect 4 is about $215 \mathrm{~m}$ southeast of the North Star Mine in the SE1/4 sec. 23, T. 2 S., R. $71 \mathrm{~W}$. It appears to be on the same fracture on which the North Star Mine is located, despite an intervening massive layer of granite gneiss. A small pit has exposed a malachite- and limonite-stained shear zone in granite gneiss and interlayered mica schist and hormblende gneiss. A small pile of ore-bearing material yielded a radiometric count of $>6000 \mathrm{cps}$.

Prospect 5 is about $290 \mathrm{~m}$ southeast of the North Star Mine in the SE1/4 sec. 23 , T. 2 S., R. $71 \mathrm{~W}$., and consists of a $30^{\circ}$ inclined shaft, which is now inaccessible, driven at N. $60 \mathrm{E}$. It is on the same fracture as the North Star Mine and Prospect 4. The shaft is driven in limonite-stained pegmatite and mica schist, but hornblende gneiss and felsic gneiss are 
TABLE 5.-Distribution and concentration of elements, relative to crustal abundance, in ore samples from the North Star Mine

[See table 3. Leaders (-) indicate no analysis or not applicable. Sample RC-167 spectrographically analyzed by L. A. Bradley]

\begin{tabular}{|c|c|c|c|c|}
\hline Element ${ }^{1}$ & $\begin{array}{l}\text { Sample RC-167 } \\
\text { Lab. No. D164643 }\end{array}$ & $\begin{array}{l}\text { Samples from } \\
\text { Adams and } \\
\text { others (1953) }\end{array}$ & Average & $\begin{array}{l}\text { Enrichment factor } \\
=\text { average/crustal } \\
\text { abundance }\end{array}$ \\
\hline U & $<0.05$ & $0.17^{2}$ & 0.11 & $<440$ \\
\hline Mo & .05 & -- & -- & 460 \\
\hline $\mathrm{Sb}$ & $<.02$ & -- & -- & $<400$ \\
\hline W & $<.02$ & -. & -- & 150 \\
\hline $\mathrm{Bi}$ & .5 & -- & -- & 556,000 \\
\hline $\mathrm{Pb}$ & .15 & $.1^{3}$ & .125 & 78 \\
\hline As & .2 & $\ldots$ & -- & 1,180 \\
\hline $\mathrm{Ag}$ & .015 & $.0159^{4}$ & .0155 & 2,200 \\
\hline $\mathrm{TI}$ & $<.005$ & -- & - & $<50$ \\
\hline $\mathrm{Hg}$ & no analysis &.- & -- & -- \\
\hline Se & -- do--s- & -- & -- & -- \\
\hline $\mathrm{s}$ & ---do---- & -- & -- & -- \\
\hline $\mathrm{Zn}$ & .07 & $.19^{3}$ & .13 & 16 \\
\hline $\mathrm{Cu}$ & 7.0 & $4.17^{2}$ & 5.6 & 1,190 \\
\hline $\mathrm{Zr}$ & .005 & $\ldots$ & -- & .3 \\
\hline $\mathrm{Nb}$ & .003 & - & -- & 1.5 \\
\hline $\mathrm{Be}$ & .0005 & -- & -- & 1.3 \\
\hline Co & .005 & -- & -- & 2.8 \\
\hline Y & .002 & -. & -- & .7 \\
\hline v & .015 & -. & -- & 1.7 \\
\hline $\mathrm{Ni}$ & .01 & -- & -- & 1.7 \\
\hline Sc & .0015 & -- & -- & 1.5 \\
\hline $\mathrm{Sr}$ & .003 & -- & -- & .1 \\
\hline $\mathrm{Cr}$ & .003 & -- & - & .4 \\
\hline $\mathrm{Ba}$ & .03 & -- & -- & .5 \\
\hline
\end{tabular}

1The following elements (with detection limits, ppm, in parentheses) were looked for and not found: B (20), Cd (50), Ce (200), Eu (100), Ge (10), Hf (100), In (10), $\mathrm{Li}(100), \mathrm{P}(2000), \mathrm{Pd}(2), \mathrm{Pt}(50), \mathrm{Re}(50), \mathrm{Sn}(10), \mathrm{Ta}(500), \mathrm{Te}(2000)$, and Th (200). Average of nine analyses.

${ }^{3}$ Average of three analyses.

${ }^{4}$ Average of six analyses.

also found nearby. Malachite, chalcocite, and molybdenite were found on its small ore dump, and scintillometer readings as high as $3000 \mathrm{cps}$ were recorded.

Prospect 6 is a small pit on a jeep road in the NW1/4 sec. 25, T. $2 \mathrm{~S} .$, R. $71 \mathrm{~W}$. It is also on the same fracture as Prospects 4 and 5 , in fractured and limonite- and malachite-stained felsic gneiss, pegmatite, and mica schist. No anomalous scintillometer readings above a background of $220-300 \mathrm{cps}$ were recorded.

Prospect 7, when visited in 1973, consisted of several pits and trenches exposing a large limonite-stained zone. A former shaft and adit shown by Sheridan and others (1967) were apparently covered. This prospect is about $18 \mathrm{~m}$ north of Prospect 6 and apparently on the same fracture and in similar country rock. Radiometric counts as high as $700 \mathrm{cps}$ were recorded. 
Prospect 8 is about $40 \mathrm{~m}$ west of the northwest section corner of section 25 on the east branch of Rogers fault. It consists of malachitestained felsic gneiss rubble along the shear zone; no anomalous counts above background were detected.

Prospect 9 is near the southeast corner of the NE $1 / 4$ sec. $26, \mathrm{~T}$. 2 S., R. 71 W., in pegmatite and hornblende gneiss. Much yellowbrown oxidized gossan is visible in a small pit.

In summary, all of the prospects, 4 through 9, show geochemical affinities to the Mena and North Star Mines rather than to the Schwartzwalder Mine.

In addition, at least seven more prospect pits, all of which are on or close to the breccia reefs, are shown on plate 1, but they show less promise than the ones described. An exploration adit is in the NW corner sec. 31, T. 2 S., R. $70 \mathrm{~W}$.

\section{DISCUSSION}

The fact that the Schwartzwalder deposit occurs in Precambrian metamorphic rock, albeit only $0.8 \mathrm{~km}$ from Phanerozoic sedimentary rock, has led some geologists to hypothesize that Laramide tectonism reactivated Proterozoic structures and remobilized Proterozoic concentrations of uranium (Fisher, 1976; DeVoto and Paschis, 1979; and Nelson and Gallagher, 1982). Earlier ideas invoked magmatic hydrothermal solutions (Sims and Sheridan, 1964) for all of the uranium deposits in the Front Range. Other genetic systems have been discussed by Rich and Barabas (1976), Maslyn (1978), and Young (1979b). The genetic systems advocated by these writers are somewhat different: Rich and Barabas postulated uranium-bearing solutions moving down from the surface into the Illinois fault, as does Maslyn; and Young postulated a circulatory system of meteoric water moving down and then being heated to move upward. Nevertheless their essential similarity is the lack of need for any contribution of uranium from magmatic sources.

The North Star and Mena deposits are geochemically somewhat different from the Schwartzwalder deposit, but such a difference may be misleading. It is conceivable that elements like bismuth, silver, and copper show enrichment near the surface (supergene enrichment). The Schwartzwalder was known as a copper prospect before the finding of uranium, and a bismuth value of 1.5 percent was recorded from the Minnesota level (near surface) by Sheridan and others (1967).

The fundamental difference, however, between the Schwartzwalder deposit and the North Star and Mena deposits is in the nature of the structure of their wall rocks. At the Schwartzwalder Mine many small fractures were opened in the cymoid zone, preparatory to later infilling by pitchblende, during Laramide rejuvenation of older structures. Presumably, structural conditions at the North Star and Mena 
TABLE 6.-Spectrographic analyses (in weight percent) of ore samples from six prospects in the Ralston Buttes district and enrichment factors of the detected elements

[Samples from Prospects 4, 5, and 8 analyzed by Leon A. Bradley; samples from Prospects 6, 7, and 9 analyzed by John C. Hamilton]

\begin{tabular}{|c|c|c|c|c|c|c|}
\hline Element ${ }^{1}$ & $\begin{array}{c}\text { Prospect } 4 \\
\text { Sample RC }-166^{2} \\
\text { Lab. No. D164642 }\end{array}$ & $\begin{array}{l}\text { Enrichment } \\
\quad \text { factor }\end{array}$ & $\begin{array}{c}\text { Prospect } 5 \\
\text { Sample RC-165 } \\
\text { Lab. No. D164641 }\end{array}$ & $\begin{array}{l}\text { Enrichment } \\
\text { factor }\end{array}$ & $\begin{array}{c}\text { Prospect } 6 \\
\text { Sample RC-130 } \\
\text { Lab. No. D163357 }\end{array}$ & $\begin{array}{c}\text { Enrichment } \\
\text { factor }\end{array}$ \\
\hline $\mathrm{Bi}$ & 0.003 & 3,330 & 0.003 & 3,330 & 0.003 & 3,330 \\
\hline$U$ & .7 & 2,800 & .07 & 280 & $<.05$ & $<200$ \\
\hline $\mathrm{Ag}$ & .015 & 2,140 & .03 & 4,290 & .005 & 714 \\
\hline $\mathrm{Cu}$ & 7.0 & 1,490 & 10.0 & 2,130 & 3.0 & 640 \\
\hline Mo & .03 & 270 & .02 & 182 & $<.0003$ & $<2.7$ \\
\hline $\mathrm{Pb}$ & .03 & 19 & .02 & 13 & .007 & 4 \\
\hline $\mathrm{Be}$ & .0015 & 4 & .0007 & 1.8 & .00015 & .4 \\
\hline $\mathrm{Zn}$ & .03 & 3.6 & $<.03$ & $<3.6$ & $<.03$ & $<4$ \\
\hline $\mathrm{V}$ & .015 & 1.7 & .015 & 1.7 & .007 & .8 \\
\hline Co & .003 & 1.7 & .005 & 2.8 & .0015 & .8 \\
\hline$M n$ & .15 & 1.5 & .07 & .7 & .07 & .7 \\
\hline $\mathrm{Nb}$ & .0015 & .8 & .002 & 1.0 & $<.001$ & $<.5$ \\
\hline $\mathrm{Sc}$ & .0007 & .7 & .0007 & .7 & .0007 & .7 \\
\hline$Y$ & .002 & .7 & .003 & 1.0 & .003 & 1.0 \\
\hline $\mathrm{Ni}$ & .003 & .5 & .01 & .5 & .003 & .5 \\
\hline $\mathrm{Cr}$ & .003 & .4 & .003 & .4 & .0015 & .2 \\
\hline $\mathrm{Ba}$ & .02 &.$?$ & .03 & .5 & .02 & .3 \\
\hline $\mathrm{Ti}$ & .15 & .3 & .15 & .3 & .15 & .3 \\
\hline $\mathrm{Zr}$ & .005 & .3 & .007 & .4 & .007 & .4 \\
\hline $\mathrm{Sr}$ & .003 & .1 & .002 & .06 & .007 & .2 \\
\hline
\end{tabular}




\begin{tabular}{|c|c|c|c|c|c|c|}
\hline Element & $\begin{array}{c}\text { Prospect } 7 \\
\text { Sample RC-131 } \\
\text { Lab. No. D163758 }\end{array}$ & $\begin{array}{l}\text { Enrichment } \\
\text { factor }\end{array}$ & $\begin{array}{c}\text { Prospect } 8 \\
\text { Sample RC-164 } \\
\text { Lab. No. D164640 }\end{array}$ & $\begin{array}{l}\text { Enrichment } \\
\text { factor }\end{array}$ & $\begin{array}{c}\text { Prospect } 9 \\
\text { Sample RC-144 } \\
\text { Lab. No. D163759 }\end{array}$ & $\begin{array}{l}\text { Enrichment } \\
\text { factor }\end{array}$ \\
\hline $\mathrm{Bi}$ & 0.003 & 3,330 & 0.03 & 33,300 & $<0.001$ & $<1,100$ \\
\hline$U$ & $<.05$ & $<200$ & $<.05$ & $<200$ & $<.05$ & $<200$ \\
\hline $\mathrm{Ag}$ & .007 & 1,000 & .007 & 1,000 & $<.00005$ & $<7$ \\
\hline $\mathrm{Cu}$ & 1.5 & 320 & 5.0 & 1,060 & .007 & 1.5 \\
\hline Mo & .007 & 64 & .002 & 18 & $<.0003$ & $<2.7$ \\
\hline $\mathrm{Pb}$ & .015 & 9 & .007 & 4 & .0015 & .9 \\
\hline $\mathrm{Be}$ & .0002 & .5 & .0002 & .5 & .00015 & .4 \\
\hline $\mathrm{Zn}$ & $<.03$ & $<4$ & $<.03$ & $<4$ & $<.03$ & $<4$ \\
\hline V & .005 & .6 & .007 & .8 & .02 & 2.2 \\
\hline Co & .0007 & .4 & .0007 & .4 & .003 & 1.7 \\
\hline $\mathrm{Mn}$ & .1 & 1 & .015 & .2 & .15 & 1.5 \\
\hline $\mathrm{Nb}$ & $<.001$ & $<.5$ & $<.001$ & $<.5$ & $<.001$ & $<.5$ \\
\hline Sc & .0007 & .7 & .0007 & .7 & .002 & 2 \\
\hline$Y$ & .002 & .7 & .0015 & .5 & .003 & 1 \\
\hline $\mathrm{Ni}$ & .0015 & .3 & .0015 & .3 & .005 & .9 \\
\hline $\mathrm{Cr}$ & .001 & .1 & .0015 & .2 & .007 & .8 \\
\hline $\mathrm{Ba}$ & .03 & .5 & .01 & .2 & .005 & .1 \\
\hline $\mathrm{Ti}$ & .05 & .1 & .1 & .2 & .2 & .4 \\
\hline $\mathrm{Zr}$ & .007 & .4 & .007 & .4 & .002 & .1 \\
\hline $\mathrm{Sr}$ & .01 & .3 & .003 & .1 & .015 & .4 \\
\hline
\end{tabular}

1 The following elements (with detection limits, ppm, in parentheses) were looked for and not found: B (20), Cd (50), Ce (200), Eu (100), Ge (10), Hf (100), In (10), Li (100), P (2000), Pd (2), Pt (50), $\operatorname{Re}(50), \operatorname{Sn}(10), \mathrm{Ta}(500)$, Te $(2000)$, Th $(200), \mathrm{Tl}(50)$, and $W(100)$.

Sample RC-166 contains 0.003 percent B.

Enrichment factor $=$ elemental value/crustal abundance. 
Mines were not as favorable. At the Schwartzwalder Mine the entire production is from a zone on the hanging wall side of the Illinois fault. This zone, no more than $200 \mathrm{~m}$ long and $90 \mathrm{~m}$ wide and extending more than $800 \mathrm{~m}$ downward from the surface, contains the main vein (Illinois) and a set of horsetail veins that dip into the Illinois. It is significant that the site of virtually all the ore deposition is in the cymoid part of the Illinois where the Illinois bends northerly from its usual northwesterly trend. This is the zone in which most of the shearing and horsetail fractures developed.

On the other hand, the deposits to the north, Mena and North Star, are characterized by relatively smaller and tighter structures resulting in much less available space for mineralization.

\section{GEOCHEMISTRY}

Nelson and Gallagher (1982) hypothesized that Laramide tectonism reactivated Proterozoic structures and remobilized Proterozoic concentrations of uranium. Citing the twofold to tenfold enrichment of silver, zinc, lead, and molybdenum in the underground host rocks (close to veins, but not including vein material) from my report (Young, 1979a), they concluded that the garnet-biotite gneiss was a likely source of uranium, molybdenum, silver, and base metals.

Whatever process of ore formation has taken place at the Schwartzwalder deposit, it has resulted in the enrichment (two times crustal abundance, or more, table 3) of at least 20 elements. To achieve the enrichment of so many elements in the pitchblende veins requires a very effective concentrating process. That this process requires the presence of openings - faults, fractures, and joints - is probably best demonstrated by considering the enrichment of elements in (1) the underground host rocks (close to veins, but not including vein material), (2) the surface country rocks in the general area of the Schwartzwalder deposit, and (3) fault breccias (both within the mine and on the surface in the Schwartzwalder area).

Table 7, taken from Young (1979a), shows, based on 35 samples, the average relative abundance of elements in the underground host rocks of the Schwartzwalder deposit. The underground host rocks consist of the following samples: 10 schist, 5 garnetiferous schist, 6 hornblende gneiss, 4 quartzite, 6 interlayered hornblende gneiss and schist, 2 interlayered schist and quartzite, and 2 fault gouge and breccia.

Table 7 shows that 11 elements are enriched two times crustal abundance or more in the underground host rocks. Most of these enriched elements are the same ones that are enriched in the pitchblende veins and undoubtedly owe their enrichment to small microfractures being impregnated by ore solutions that coursed through the channels where 
TABLE 7.-Relative abundance of elements in underground host rocks of the Schwartzwalder deposit

[Averages based on 35 samples. Crustal abundances same as in table 3]

\begin{tabular}{|c|c|c|}
\hline Element & $\begin{array}{l}\text { Average } \\
\text { percent }\end{array}$ & $\begin{aligned} & \text { Enrichment factor } \\
= & \text { average/crustal abundance }\end{aligned}$ \\
\hline $\mathrm{Se}$ & 0.000138 & 27.6 \\
\hline$S$ & 1.19 & 25.0 \\
\hline Mo & .0012 & 11.0 \\
\hline $\mathrm{B}$ & .0097 & 8.0 \\
\hline$U^{1}$ & .0086 & 5.5 \\
\hline $\mathrm{Ag}$ & .000035 & 5.0 \\
\hline $\mathrm{Zn}$ & .034 & 4.0 \\
\hline $\mathrm{Pb}$ & .0048 & 3.0 \\
\hline $\mathrm{Sc}$ & .0021 & 2.1 \\
\hline $\mathrm{Mn}$ & .198 & 2.0 \\
\hline $\mathrm{Fe}$ & 9.3 & 2.0 \\
\hline $\mathrm{F}$ & .127 & 1.9 \\
\hline $\mathrm{Cu}$ & .0088 & 1.9 \\
\hline V & .0158 & 1.8 \\
\hline Co & .0031 & 1.7 \\
\hline $\mathrm{Hg}$ & .000012 & 1.5 \\
\hline $\mathrm{La}$ & .0035 & 1.2 \\
\hline $\mathrm{Ni}$ & .0061 & 1.1 \\
\hline$Y$ & .0027 & 1.0 \\
\hline $\mathrm{Zr}$ & .0150 & .9 \\
\hline $\mathrm{Mg}$ & 1.64 & .88 \\
\hline $\mathrm{Ti}$ & .0031 & .7 \\
\hline $\mathrm{Cr}$ & .0061 & .7 \\
\hline $\mathrm{Ca}$ & 1.72 & .6 \\
\hline $\mathrm{Ba}$ & .0340 & .5 \\
\hline $\mathrm{Be}$ & .00019 & .5 \\
\hline $\mathrm{Sr}$ & .0150 & .4 \\
\hline
\end{tabular}

$1_{\text {Equivalent uranium. Crustal abundance is based on } 13 \mathrm{ppm}}$ thorium and $2.5 \mathrm{ppm}$ uranium.

pitchblende is now found. This conclusion seems reasonable because the surface country rocks in the general area of the Schwartzwalder deposit only show enrichment in two elements, boron and fluorine, trace elements notably enriched in the Front Range.

Based on 34 samples, table 8 shows the average relative abundance of elements in the surface country rocks, which consist of the following samples: 14 schist, 7 granite gneiss, 5 quartzite, 3 garnetiferous schist, 3 hornblende gneiss, and 2 magnetite and quartz layer.

The fact that the surface country rock shows no enrichment of any 
TABLE 8.-Relative abundance of elements in surface country rocks near the Schwartzwalder deposit

[Averages based on 34 samples. Crustal abundances same as in table 3]

\begin{tabular}{ccc}
\hline Element & $\begin{array}{c}\text { Average } \\
\text { percent }\end{array}$ & $\begin{array}{c}\text { Enrichment factor } \\
\text { average/crustal abundance }\end{array}$ \\
\hline $\mathrm{B}$ & 0.0090 & 7.5 \\
$\mathrm{~F}$ & .1820 & 2.8 \\
$\mathrm{~Pb}$ & .0030 & 1.9 \\
$\mathrm{La}$ & .0053 & 1.8 \\
$\mathrm{Fe}$ & 6.3 & 1.4 \\
$\mathrm{Mn}$ & .117 & 1.2 \\
$\mathrm{~V}$ & .0092 & 1.0 \\
$\mathrm{Co}$ & .0018 & 1.0 \\
$\mathrm{Y}$ & .0028 & 1.0 \\
$\mathrm{Zr}$ & .0168 & 1.0 \\
$\mathrm{U} 1$ & $<.003$ & $\sim 1.0$ \\
$\mathrm{Mo}$ & $<.0005$ & 1.0 \\
$\mathrm{Cr}$ & .0066 & .8 \\
$\mathrm{Hg}$ & .000006 & .8 \\
$\mathrm{Ni}$ & .004 & .7 \\
$\mathrm{~S}$ & .034 & .7 \\
$\mathrm{Ba}$ & .043 & .7 \\
$\mathrm{Ti}$ & .22 & .5 \\
$\mathrm{Be}$ & .0002 & .5 \\
$\mathrm{Mg}$ & .8 & .4 \\
$\mathrm{Sr}$ & .015 & .4 \\
$\mathrm{Cu}$ & .0016 & .3 \\
$\mathrm{Ca}$ & .7 & .2 \\
\hline 1 & & \\
\hline
\end{tabular}

$1_{\text {Equivalent uranium. Crustal abundance is based on } 13 \mathrm{ppm}}$ thorium and $2.5 \mathrm{ppm}$ uranium.

The average value for $\mathrm{Hg}$ is based on 29 samples.

of the elements that are enriched in the pitchblende veins is evidence that the country rock has no genetic relation to the Schwartzwalder deposit.

On the other hand, the fault breccias, table 9 , show a definite genetic link with the Schwartzwalder deposit, or to put it another way, ore-forming processes in the fault breccias are the same as those that operated in the pitchblende veins. The underground fault breccias show enrichment (two times crustal abundance, or more) in 12 elements, most of which are enriched in the pitchblende veins, and the surface fault breccias show enrichment in 7 elements. Noticeable is the general diminished enrichment in the surface fault brecias, compared to the underground fault breccias, undoubtedly due to leaching by meteoric water. 
TABLE 9.-Relative abundance of elements in nine surface and two underground fault breccias

[Crustal abundances same as in table 3. n.d., not determined]

\begin{tabular}{|c|c|c|c|c|}
\hline \multirow[b]{2}{*}{ Element } & \multicolumn{2}{|c|}{ Surface fault breccias } & \multicolumn{2}{|c|}{ Underground fault breccias } \\
\hline & $\begin{array}{l}\text { Average } \\
\text { percent }\end{array}$ & $\begin{aligned} & \text { Enrichment factor } \\
&= \text { average } / \text { crustal } \\
& \text { abundance }\end{aligned}$ & $\begin{array}{l}\text { Average } \\
\text { percent }\end{array}$ & $\begin{aligned} & \text { Enrichment factor } \\
&= \text { average/crustal } \\
& \text { abundance }\end{aligned}$ \\
\hline$u^{1}$ & $<0.003$ & $\sim 1.0$ & 0.075 & 300. \\
\hline Mo & .0005 & 4.5 & .0175 & 160. \\
\hline $\mathrm{Se}$ & n.d. & n.d. & .00027 & 54. \\
\hline S & .24 & 5.1 & 2.5 & 53. \\
\hline $\mathrm{Ag}$ & .0001 & 14. & .00008 & 11 . \\
\hline $\mathrm{Zn}$ & $<.02$ & $<2.4$ & .085 & 10.2 \\
\hline $\mathrm{Hg}$ & .00001 & 1.3 & .00007 & 8.8 \\
\hline $\mathrm{Pb}$ & .0027 & 1.7 & .0135 & 8. \\
\hline Mn & $>.1$ & $>1$ & .3 & 3. \\
\hline B & .002 & 1.7 & .0030 & 2.5 \\
\hline $\mathrm{Fe}$ & 10 . & 2.2 & 11. & 2.4 \\
\hline v & .02 & 2.2 & .02 & 2.2 \\
\hline $\mathrm{Cu}$ & .023 & 4.9 & .008 & 1.7 \\
\hline Sc & .0015 & 1.5 & .013 & 1.3 \\
\hline$F$ & .243 & 3.7 & .078 & 1.2 \\
\hline Co & .0032 & 1.8 & .002 & 1.1 \\
\hline $\mathrm{Mg}$ & 1.2 & .6 & 1.8 & 1. \\
\hline $\mathrm{Ca}$ & 4.6 & 1.6 & 3. & 1. \\
\hline La & .003 & 1. & .0025 & .9 \\
\hline $\mathrm{Be}$ & .0002 & .5 & .00035 & .9 \\
\hline $\mathrm{Zr}$ & .009 & .5 & .015 & .9 \\
\hline$Y$ & .0025 & .9 & .025 & .9 \\
\hline $\mathrm{Ni}$ & .0045 & .8 & .0045 & .8 \\
\hline $\mathrm{Sr}$ & .02 & .6 & .02 & .6 \\
\hline $\mathrm{Ti}$ & .24 & .5 & .2 & .4 \\
\hline $\mathrm{Cr}$ & .006 & .7 & .0025 & .3 \\
\hline $\mathrm{Ba}$ & .067 & 1. & .02 & .3 \\
\hline
\end{tabular}

$1_{\text {Equivalent uranium. For surface fault breccias, crustal abundance is }}$ based on $13 \mathrm{ppm}$ thorium and $2.5 \mathrm{ppm}$ uranium. For underground fault breccias most eU is caused by uranium; nence, crustal abundance is based on $2.5 \mathrm{ppm}$ uranium.

\section{REFERENCES}

Adams, J. W., Gude, A. J., 3rd, and Beroni, E. P., 1953 [1954], Uranium occurrences in the Golden Gate Canyon and Ralston Creek areas, Jefferson County, Colorado: U.S. Geological Survey Circular 320, 16 p.

Derzay, R. C., and Bird, A. G., 1976, Economic geology of uranium deposits in the Ralston Creek area, Jefferson County, Colorado: U.S. Energy Research and Development Administration Open File Report RME-1077, 42 p.

DeVoto, R. H., and Paschis, J. A., 1979, Geology of uranium vein deposits (including Schwartzwalder Mine) in Proterozoic metamorphic rocks, Front Range, Colorado: 
International Symposium on the Pine Creek Geosyncline, N. T., Australia, Sydney, June 4-8, 1979, Extended Abstract., p. 51-6.

Down, G. R., and Bird, A. G., 1965, The Schwartzwalder uranium mine, Jefferson County, Colorado: Mountain Geologist, v. 2, no. 4, p. 183-191.

Fisher, J. C., 1976, Remote sensing applied to exploration for vein-type uranium deposits, Front Range, Colorado: Colorado School of Mines Ph.D. thesis, $158 \mathrm{p}$.

Frondel, Clifford, 1958, Systematic mineralogy of uranium and thorium: U.S. Geological Survey Bulletin 1064, $400 \mathrm{p}$.

Lovering, T. S., and Goddard, E. N., 1950, Geology and ore deposits of the Front Range, Colorado: U.S. Geological Survey Professional Paper 223, 319 p.

Marvin, R. F., Young, E. J., Mehnert, H. H., and Naeser, C. W., 1974, Summary of radiometric age determinations of Mesozoic and Cenozoic igneous rocks and uranium and base metal deposits in Colorado: Isochron/West, no. 11, $41 \mathrm{p}$.

Maslyn, R. M., 1978, An epigenetic model for the formation of the Schwartzwalder uranium deposit: Economic Geology, v. 73, no. 4, p. 552-557.

Nelson, C. E., and Gallagher, J. R. L., 1982, Proterozoic origins of uranium mineralization in the Colorado Front Range: Economic Geology, v. 77, p. 1221-1225.

Peterman, Z. E., Hedge, C. E., and Braddock, W. A., 1968, Age of Precambrian events in the northeastern Front Range, Colorado: Journal of Geophysical Research, v. 73, no. 6, p. 2277-2296.

Rich, R. A., and Barabas, A. H., 1976, Mineralogy, paragenesis, fluid inclusions, and origin of the Schwartzwalder uranium mine, Jefferson County, Colorado: Geological Society of America Abstracts with Programs, v. 8, no. 6, p. 1068.

Sheridan, D. M., Maxwell, C. H., and Albee, A. L., 1967, Geology and uranium deposits of the Ralston Buttes district, Jefferson County, Colorado, with sections on Paleozoic and younger sedimentary rocks, by Richard Van Horn: U.S. Geological Survey Professional Paper 520, $121 \mathrm{p}$.

Sims, P. K., and Sheridan, D. M., 1964, Geology of uranium deposits in the Front Range, Colorado: U.S. Geological Survey Bulletin 1159, 116 p.

Taylor, R. B., 1975, Geologic map of the Black Hawk quadrangle, Gilpin, Jefferson, and Clear Creek Counties, Colorado: U.S. Geological Survey Geologic Quadrangle Map GQ-1248.

Tweto, Ogden, 1977, Nomenclature of Precambrian rocks in Colorado: U.S. Geological Survey Bulletin 1422-D, 22 p.

Tweto, Ogden, and Sims, P. K., 1960, Relation of the Colorado mineral belt to Precambrian structure: U.S. Geological Survey Professional Paper 400-B, p. B8-B10.

1963, Precambrian ancestry of the Colorado mineral belt: Geological Society of America Bulletin, v. 74, no. 8, p. 991-1014.

Van Horn, Richard, 1976, Geology of the Golden quadrangle, Colorado: U.S. Geological Survey Professional Paper 872, $116 \mathrm{p}$.

Vinogradov, A. P., 1962, Average contents of chemical elements in the principal types of igneous rocks of the earth's crust [in Russian]: Geokhimiya, 1962, no. 7, p. $555-571$; translation in Geochemistry, 1962, no. 7, p. 641-664.

Walker, G. W., and Adams, J. W., 1963, Mineralogy, internal structural and textural characteristics, and paragenesis of uranium-bearing veins in the conterminous United States: U.S. Geological Survey Professional Paper 455-D, p. 55-90.

Young, E. J., 1977, Geologic, radiometric, and mineralogic maps and underground workings of the Schwartzwalder uranium mine and area, Jefferson County, Colorado: U.S. Geological Survey Open-File Report 77-725, 41 p.

1979a, Analytical data on the Schwartzwalder uranium deposit, Jefferson County, Colorado: U.S. Geological Survey Open-File Report 79-968, 34 p., 18 tables.

1979b, Genesis of the Schwartzwalder uranium deposit, Jefferson County, Colorado: University of Wyoming, Contributions to Geology, Uranium Issue II, v. 17 , no. 2, p. 179-186. 